\title{
Short-Term Sea Level Changes of the Upper Cretaceous Carbonates: Calibration between Palynomorphs Composition, Inorganic Geochemistry, and Stable Isotopes
}

\author{
Ahmed Mansour ${ }^{1}(\mathbb{D})$, Thomas Gentzis ${ }^{2, *(\mathbb{D})}$, Michael Wagreich ${ }^{3}$ (D) , Sameh S. Tahoun ${ }^{4}(\mathbb{D})$ \\ and Ashraf M.T. Elewa ${ }^{1}$ \\ 1 Geology Department, Faculty of Science, Minia University, Minia 61519, Egypt; \\ ahmedmans48@mu.edu.eg (A.M.); ashraf.aleiwa@mu.edu.eg (A.M.T.E.) \\ 2 Core Laboratories LP, 6316 Windfern Road, Houston, TX 77040, USA \\ 3 Department of Geology, Faculty of Earth Sciences, Geography and Astronomy, University of Vienna, \\ 1090 Vienna, Austria; michael.wagreich@univie.ac.at \\ 4 Geology Department, Faculty of Science, Cairo University, Giza 12613, Egypt; stahoun@yahoo.com \\ * Correspondence: thomas.gentzis@corelab.com; Tel.: +1-713-328-2556
}

Received: 10 November 2020; Accepted: 4 December 2020; Published: 7 December 2020

\begin{abstract}
Widespread deposition of pelagic-hemipelagic sediments provide an archive for the Late Cretaceous greenhouse that triggered sea level oscillations. Global distribution of dinoflagellate cysts (dinocysts) exhibited a comparable pattern to the eustatic sea level, and thus, considered reliable indicators for sea level and sequence stratigraphic reconstructions. Highly diverse assemblage of marine palynomorphs along with elemental proxies that relate to carbonates and siliciclastics and bulk carbonate $\delta^{13} \mathrm{C}$ and $\delta^{18} \mathrm{O}$ from the Upper Cretaceous Abu Roash A Member were used to reconstruct short-term sea level oscillations in the Abu Gharadig Basin, southern Tethys. Additionally, we investigated the relationship between various palynological, elemental, and isotope geochemistry parameters and their response to sea level changes and examined the link between these sea level changes and Late Cretaceous climate. This multiproxy approach revealed that a long-term sea-level rise, interrupted by minor short-term fall, was prevalent during the Coniacian-earliest Campanian in the southern Tethys, which allowed to divide the studied succession into four complete and two incomplete $3^{\text {rd }}$ order transgressive-regressive sequences. Carbon and oxygen isotopes of bulk hemipelagic carbonates were calibrated with gonyaulacoids and freshwater algae (FWA)-pteridophyte spores and results showed that positive $\delta^{13} \mathrm{C}_{\text {carb }}$ trends were consistent, in part, with excess gonyaulacoid dinocysts and reduced FWA-spores, reinforcing a rising sea level and vice versa. A reverse pattern was shown between the $\delta^{18} \mathrm{O}_{\text {carb }}$ and gonyaulacoid dinocysts, where negative $\delta^{18} \mathrm{O}_{\text {carb }}$ trends were slightly consistent with enhanced gonyaulacoid content, indicating a rising sea level and vice versa. However, stable isotope trends were not in agreement with palynological calibrations at some intervals. Therefore, the isotope records can be used as reliable indicators for reconstructing changes in long-term sea level rather than short-term oscillations.
\end{abstract}

Keywords: sequence palynology; dinoflagellate cysts; gonyaulacoid dinocysts; stable carbon and oxygen isotopes; major and trace elements; southern Tethys; Late Cretaceous sea level

\section{Introduction}

From the onset of the Late Cretaceous, a global long-term marine sea-level high occurred with a peak estimate of 170 to $250 \mathrm{~m}$ above the present sea level (Figure 1) [1-3]. This caused a major 
transgressive event in the Tethys Ocean that almost flooded northern Africa [2] and extended beyond the Egyptian borders to the south in the Khartoum, Melut, and Muglad basins of southern Sudan [4]. Short-term stratigraphic sequences, mainly third and fourth order, and sea level reconstruction are critical for understanding local to regional environmental processes and related deposition of sediments from the southern Tethys, particularly the Abu Gharadig Basin, north Western Desert, Egypt.

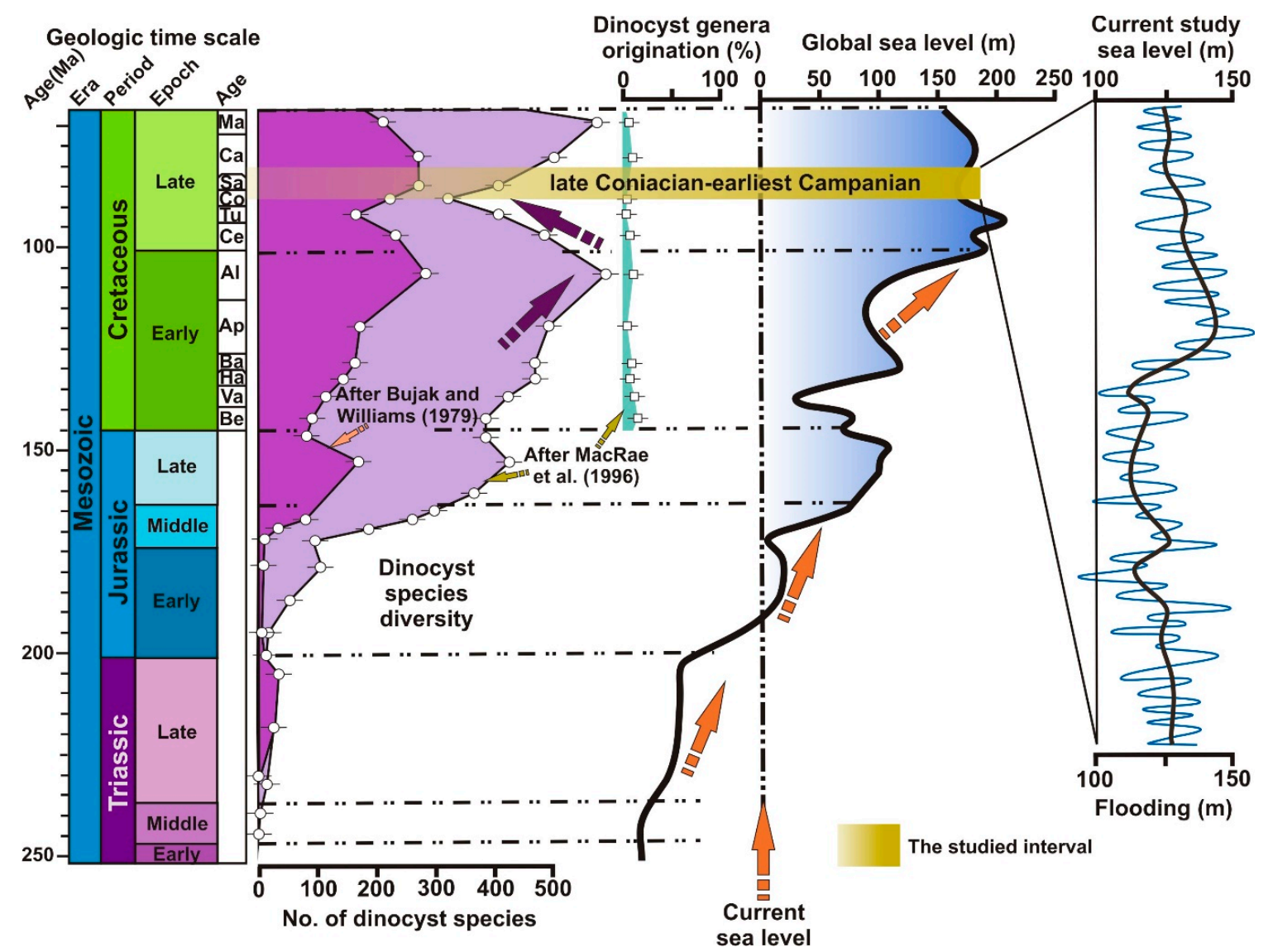

Figure 1. Global dinoflagellate cyst diversity through the Mesozoic [5,6] as well as absolute percentage of dinoflagellate cyst genera origination during the Cretaceous [6] and their significant positive correlation with the eustatic sea level [2]. Current study sea level curve is constructed based on various palynological components with further details discussed below. The geologic time interval is referred to GTS2012 [7]. Be, Berriasian; Va, Valanginian; Ha, Hauterivian; Ba, Barremian; Ap, Aptian; Al, Albian; $\mathrm{Ce}$, Cenomanian; Tu, Turonian; Co, Coniacian; Sa, Santonian; Ca, Campanian; Ma, Maastrichtian.

Correlating the stratigraphic vertical variations in the relative evenness and richness of marine phytoplankton versus terrestrially derived palynomorphs is widely acknowledged as an approach to define the magnitude of sea-level transgressive-regressive trends and systems tracts in offshore sedimentary facies [5,6,8-14]. Most interestingly, the organic-walled dinocysts species diversity showed significantly similar trends to the eustatic sea level curve from their first appearance during the Triassic up to the Cretaceous (Figure 1), make them reliable indicators of sea level transgression-regression cycles [12,14,15]. Common types of sequence stratigraphy were summarized into depositional, genetic, and transgressive-regressive sequences [16]. However, thick stratigraphic intervals of pelagic-hemipelagic carbonate sediments make it difficult to delineate depositional and/or genetic sequence compared to siliciclastic-carbonate successions as is the case in the Abu Roash A Member. In this study, the transgressive-regressive sequence stratigraphy [16,17] was used because of the carbonate nature of the studied interval and easiness of reconstruction within a stratigraphic sequence. 
Generally, the content of major and trace elements and their ratios in sediments are used to investigate redox conditions, continental weathering, role of terrestrial/riverine input, and fluctuations in relative sea level [12,18-23]. Carbon and oxygen isotope chemostratigraphy are commonly used as a reliable proxy for greenhouse/icehouse climatic, oceanographic, and sea level investigations [20,24-26]. In addition to the palynological- and geochemical-based sea level reconstructions, stable carbon and oxygen isotope records were used herein for their reliability as proxies for sea level changes side by side with several palynomorphs categories.

The current study is part of a larger project of the relatively understudied Abu Roash Formation in the Abu Gharadig Basin of the north Western Desert, Egypt. In this context, the most prominent publications related to the Abu Roash A Member focused on detailed biostratigraphy, palynological, and palynofacies analysis, redox conditions and other environmental aspects [14,23]. Therefore, the aim of the current study is to: (1) investigate the Tethyan widespread transgression and reconstruct short-term changes in sea level and systems tracts through the Abu Gharadig Basin, based on palynomorphs composition; (2) investigate the relationship and overall trends between various palynological categories and elemental geochemistry and stable isotope records; and (3) examine whether there is a relationship and/or a link between Late Cretaceous climate and sea level changes.

\section{Geologic and Stratigraphic Settings}

In this part of the southern Tethys where the study area is located, a NE-SW extensional regime was active from the Jurassic to Early Cretaceous due to the Alpine Orogeny. This resulted in a NW-SE to WNW-ESE series of normal faults and the formation of most hydrocarbon basins over northern Africa (i.e., Egypt, [4,27]), whereby such deep crustal tectonics have influenced the Abu Gharadig Basin [28] (Figure 2). During the Late Cretaceous (starting at the Turonian), a change in the regional stress field in northern Egypt led to a deformation of the former extensional structural by dextral wrenching [29]. Subsequently, this wrenching resulted in the formation of NE-SW compressional and NW-SE to WNW-ESE extensional oriented structure, which culminated with a period of uplift and erosion during the Santonian [30] (Figure 2B). 


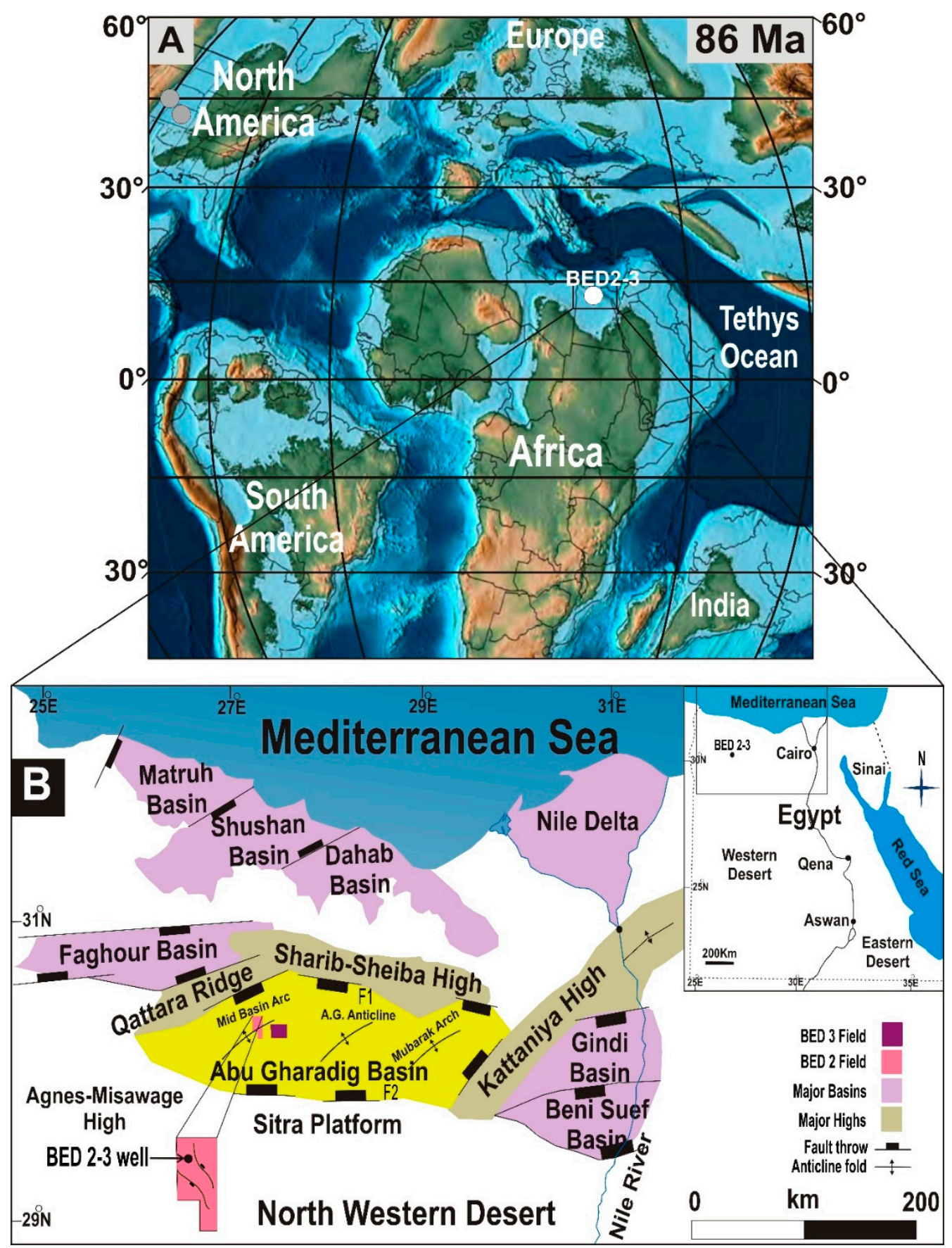

Figure 2. (A) Paleogeographic map during the Coniacian-Santonian (including topography and bathymetry, after [31]. (B) Location map with major structural features of the north Western Desert, including the BED2-3 well in the Abu Gharadig Basin.

Deposition within the Abu Gharadig Basin appears to have started with the beginning of the first Mesozoic sedimentary cycle [32]. A slow southward transgression of the Tethys reached the Abu Gharadig Basin during the Middle Jurassic, which formed an E-W trending local embayment. During the Cretaceous, the basin subsided actively, whereby more than $1800 \mathrm{~m}$ of sediments were deposited and represented by the Shaltut, Kharita, and Alamein formations (Figure 3). During the Upper Cretaceous Tethyan transgression, a total thickness of ca. $2000 \mathrm{~m}$ was deposited in Abu Gharadig Basin from fluvio-marginal marine to shallow and open marine Bahariya, Abu Roash, and Khoman formations, respectively [14], suggesting a rapidly subsiding basin floor triggered by major faults 
(F1-F2, Figure 2B). The Abu Roash A Member is composed of thick hemipelagic carbonates with minor intercalations of marls and calcareous shales of up to $180 \mathrm{~m}$ (Figure 3). It was deposited in a distal inner to middle shelf environments based on paleontological and palynological inferences [14,33]. Age assessment of the Abu Roash A Member was carried out based on age-diagnostic foraminiferal biostratigraphy [33]. Recently, the Abu Roash A Member was fully investigated and assigned to an age not younger than late Coniacian-earliest Campanian based on the first downhole occurrence of marker dinocysts taxa [14], including Isabelidinium belfastense, Odontochitina operculate, O. porifera, Dinogymnium acuminatum, Nelsoniella aceras, Cyclonephelium filoreticulatum, and Spinidinium echinoideum.

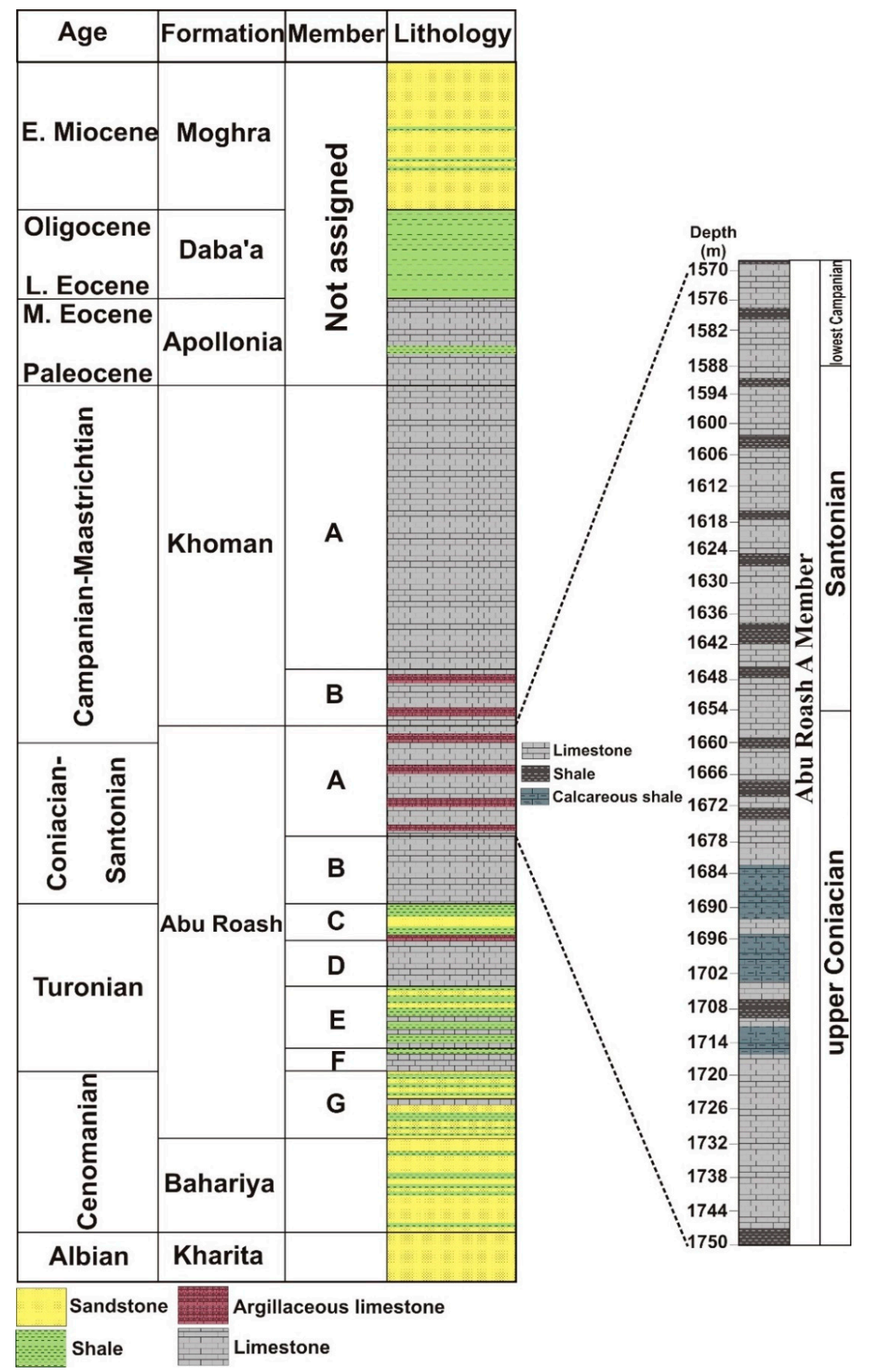

Figure 3. Complete lithologic column from the Albian to lower Miocene of the BED2-3 well that was drilled in the Abu Gharadig Basin, to the left. The lithologic column of the studied Abu Roash A Member $(180 \mathrm{~m})$, is expanded to the right. 


\section{Materials and Methods}

The samples used in this study were obtained from the BED2-3 well $\left(29^{\circ} 53^{\prime} 13^{\prime \prime} \mathrm{N}\right.$ and $\left.27^{\circ} 42^{\prime} 11^{\prime \prime} \mathrm{E}\right)$ drilled by the Bedr El Din Petroleum Company, Cairo, Egypt, in the BED2 gas field in the western flank of the Abu Gharadig Basin. A total of 31 cuttings samples representing the Abu Roash A Member at depths from 1570 to $1750 \mathrm{~m}$ were used for palynological analysis. This member is composed of hemipelagic limestone with a few thin marl and calcareous shale intercalations (Figure 3).

\subsection{Palynological Screening}

Approximately $15 \mathrm{~g}$ per sample were treated in concentrated $\mathrm{HCl}(35 \%)$ and $\mathrm{HF}(40 \%)$ acids following the standard palynological processing technique to recover the particulate organic matter [34]. Following acid reactions, the entire residue was sieved using a nylon mesh $(10 \mu \mathrm{m})$ and mounted on two slides using Canada Balsam. Oxidative agents, such as nitric acid and/or hydroxides, were avoided. For microscopic investigations, a transmitted light OMAX ToupView microscope (OMAX microscope, China) equipped with a digital camera was used. All slides were stored in the Micropaleontology-Stratigraphy Lab, Geology Department, Faculty of Science, Minia University, Minia, Egypt.

For proper palynomorphs counting that is used to represent species richness, several statistical approaches were proposed as summarized in [13]. The approach of Tyson [9] was followed, who suggested that a total of 200-300 palynomorphs count is practical and sufficient for depositional environmental reconstruction. The counted palynomorphs throughout the Abu Roash A Member are reported in Supplementary Table S1. The dinocyst diversity was calculated using the Shannon Diversity Index (SDI).

\subsection{Bulk-Rock Geochemistry, Organic Carbon, and $\mathrm{CaCO}_{3}$ Analyses}

For geochemical analysis, approximately $10 \mathrm{~g}$ aliquot of each bulk-rock sample were milled into powder of ca. $100 \mu \mathrm{m}$ and placed in a plastic sample cup after covering the cup from the base of a $25 \mathrm{~mm}$ diameter by thin plastic wrap. Each sample cup was placed on the central stage of the TRACER IV-SD the Bruker AXS and adjusted for quantitative measurements using energy-dispersive $x$-ray fluorescence "hand-held ED-XRF" at the Department of Geodynamics and Sedimentology, Faculty of Earth Sciences, Geography and Astronomy, University of Vienna, Vienna, Austria. Twenty-eight samples were measured for major $(\mathrm{Si}, \mathrm{Ca}, \mathrm{Al}, \mathrm{Mg}, \mathrm{Fe}, \mathrm{K}, \mathrm{P}, \mathrm{Ti}, \mathrm{Mn}$ ) and trace elements $(\mathrm{Co}, \mathrm{Cr}, \mathrm{Ni}$, $\mathrm{V}, \mathrm{Zr}, \mathrm{Zn}, \mathrm{Sr}, \mathrm{Ba}, \mathrm{Ce}, \mathrm{Pb}$, and Mo, Supplementary Table S2) under Dual Mode analysis with two excitation energies. The low energy $(15 \mathrm{kV})$ was used to measure major elements along with $\mathrm{Cr}$, $\mathrm{V}$, and $\mathrm{Ni}$ ), whereas the high-energy $(40 \mathrm{kV})$ was used to measure the remaining trace elements. Spectra software was loaded into proprietary Bruker AXS calibration (SPECTRAEDX S2 CONFIGURATION, Bruker AXS GmbH, Karlsruhe, Germany). A reference concentration of each major and trace element was estimated against the concentration of the element using interelement slope and baseline that corrected for peak heights from an ED-XRF system. Internal standards were used for carbonate and siliciclastic compositions using ICP-MS. The analytical error was ca. 5\% and the detection limit for trace elements was usually $5-10 \mathrm{ppm}$. Some samples were measured three times to obtain a reproducibility index. The analytical precision was $+/-1.5 \%$.

Total organic carbon (TOC) content was measured using a powdered aliquot of ca. $100 \mathrm{mg}$ per sample that was cleaned to remove drilling additives (e.g., oil-based mud) using dichloromethane:methanol (87:13) for $24 \mathrm{~h}$ and then dried at $50{ }^{\circ} \mathrm{C}$ for $3 \mathrm{~h}$. Subsequently, the samples were treated by $\mathrm{HCl}(35 \%)$ for $10 \mathrm{~h}$ to remove inorganic carbon. Distilled water was used to rinse the $\mathrm{HCl}$ before analysis. Organic carbon content was measured using a LECO C230 analyzer (LECO Corp., St. Joseph, MI, USA) at $1100{ }^{\circ} \mathrm{C}$ at the Stratochem Services Lab, Cairo, Egypt. Analytical precision of TOC ranged between +0.02 and $0.04 \mathrm{wt} . \%$. 
A total of 28 samples were measured for their $\mathrm{CaCO}_{3}$ content by dissolving an aliquot of ca. $65 \mathrm{mg}$ of each powdered sample in $\mathrm{HCl}$ (25\%) using the Müller-Gastner-Bomb [35].

\subsection{Stable Isotope Measurements}

Twenty-three samples of the Abu Roash A Member were selected for their bulk carbonate carbon $\left(\delta^{13} \mathrm{C}_{\text {carb }}\right)$ and oxygen $\left(\delta^{18} \mathrm{O}_{\text {carb }}\right)$ isotopes and were measured using a ThermoFinnigan DeltaplusXL mass spectrometer (Thermo Fisher Scientific Inc., Waltham, MA, USA) with a GasBench II (Supplementary Table S3). The stable isotope analysis was carried out at the Institute of Geology, University of Innsbruck, Innsbruck, Austria, following the described preparation technique in [36]. Herein, $\delta^{13} \mathrm{C}_{\text {carb }}$ principally reflects the $\delta^{13} \mathrm{C}$ of seawater and was used along with the $\delta^{18} \mathrm{O}_{\text {carb }}$ record to rigorously test and indicate the relationship with the relative sea level change.

\section{Results}

\subsection{Palynomorphs Composition}

Within the succession, a highly diverse assemblage of different palynomorphs categories was identified (Supplementary Table S1). For the Abu Roash A Member, dinocysts and microforaminiferal test linings (MFTLs) were the most common constituents of the total palynomorphs content (TPC) and estimated to be 71.9-28.4\% (avg. 57.5\%) and 68.6-12.6\% (avg. 29.6\%, Table 1), respectively. The total dinocyst content (TDC) was dominated by a relatively high abundance of proximo-chorate and proximate gonyaulacoids (97.5-29.4\%, avg. 56\% of TDC) compared to moderate peridinioids (48.9-1.5\%, avg. $27.9 \%$ of TDC, Table 1 ). The relative abundance of proximo-chorate and proximate gonyaulacoids are represented mostly by Downiesphaeridium? diversispinosum, D. aciculare, Downiesphaeridium sp., Spiniferites ramosus, S. bulloideus, S. multibrevis, Spiniferites sp., Circulodinium cf. distinctum, Heterosphaeridium verdieri, H. cordiforme, Heterosphaeridium sp., Tenua hystrix, Trichodinium castanea, Cyclonephelium compactum, Canningia reticulata Xenascus sp., and Batiacasphaera sp. The peridinioid dinocysts are characterized by a plethora of Bosedinia laevigata, B. alveolata, B. spinosa, Subtilisphaera perlucida, S. senegalensis, Subtilisphaera sp., Trithyrodinium suspectum, Chatangiella williamsii, Chatangiella sp., Alterbidinium sp., Isabelidinium acuminatum, Isabelidinium sp., Palaeohystrichophora infusorioides, and Elytrocysta druggii.

The chorate gonyaulacoid dinocysts (28.7-1, avg. 16.1\% of TDC, Figure 4, Table 1) are least abundant and dominated by Exochosphaeridium bifidium, Oligosphaeridium complex, Oligosphaeridium sp., Coronifera oceanica, Surculosphaeridium? longifurcatum, Surculosphaeridium sp., Pervosphaeridium pseudhystrichodinium, Pervosphaeridium sp., Hystrichodinium pulchrum, and Florentinia berran. Sporadic occurrences of other peridinioid and gonyaulacoid dinocyst species are indicated in Supplementary Table S1.

In contrast, terrestrial sporomorphs and freshwater algae (FWA) represent moderate to low abundance that were estimated to be $14-0.5 \%$ (avg. 5\% of TPC) and $25-0 \%$ (avg. 4.7\%, Table 1). These contents were shown to fluctuate with falling and rising events of sea level (Figure 4). Pollen grains within the Abu Roash A Member are dominated by Aruacariacites australis, A. hungaricus, Aruacariacites sp., Tricolpites sp., Foveotricolpites giganteus, Foveotricolpites sp., and Spheripollenites sp. Sparse records of pteridophyte spores are represented mainly by Cyathidites australis, Cyathidites sp., Deltoidospora minor, Deltoidospora sp. Additionally, the most common FWA is characterized by Pediastrum boryanum and Pediastrum sp. along with occasional occurrences of Scenedesmus sp., Crassosphaera ornate, and Ovoidites parvaus. 
Table 1. Counted palynomorphs constituents and percentages encountered within the studied succession from the BED 2-3 well. MFTLs $=$ Microforaminiferal test linings, FWA $=$ Freshwater algae, $\mathrm{PMI}=$ Palynological marine index .

\begin{tabular}{|c|c|c|c|c|c|c|c|c|c|c|}
\hline \multirow{2}{*}{ Samples } & \multirow{2}{*}{$\begin{array}{c}\text { Dinocyst } \% \text { of } \\
\text { Total Palynomorphs }\end{array}$} & \multicolumn{3}{|c|}{ Dinocyst Groups of Total Dinocyst \% } & \multicolumn{2}{|c|}{ Dinocyst Diversity } & \multirow{2}{*}{ MFTLs (\%) } & \multirow{2}{*}{ FWA (\%) } & \multirow{2}{*}{ Sporomorphs (\%) } & \multirow{2}{*}{ PMI } \\
\hline & & Peridinioid & Chorate Gon. & Other Gony. & Shanon Index & No. of Species & & & & \\
\hline 1570 & 47.1 & 48.9 & 21.7 & 29.4 & 3.63 & 48 & 29.4 & 4.41 & 12.25 & 486 \\
\hline 1576 & 61.7 & 46.3 & 10.6 & 43.1 & 3.56 & 50 & 25.9 & 0.99 & 7.46 & 1022 \\
\hline 1582 & 62.3 & 46.7 & 10.4 & 43 & 3.81 & 59 & 13.9 & 2.33 & 13.95 & 500 \\
\hline 1588 & 38.6 & 34.4 & 14 & 51.6 & 3.6 & 47 & 32.6 & 19.92 & 7.20 & 265 \\
\hline 1594 & 46.4 & 18.8 & 16.8 & 64.4 & 3.43 & 40 & 31.4 & 17.73 & 4.09 & 351 \\
\hline 1600 & 65.7 & 27.1 & 19.3 & 53.6 & 3.6 & 47 & 29.2 & 1.39 & 2.32 & 2311 \\
\hline 1606 & 52.7 & 39.5 & 10.1 & 50.5 & 3.53 & 42 & 30.2 & 2.44 & 12.68 & 544 \\
\hline 1612 & 55.6 & 24.4 & 26.1 & 49.6 & 3.65 & 47 & 35.9 & 0 & 6.08 & 1436 \\
\hline 1618 & 54.8 & 35.4 & 6.2 & 58.4 & 3.48 & 44 & 31.3 & 1.92 & 6.73 & 1000 \\
\hline 1624 & 66.8 & 29.9 & 9.7 & 60.4 & 3.57 & 45 & 23.1 & 1.38 & 3.23 & 1882 \\
\hline 1630 & 62.4 & 13.6 & 17.1 & 69.3 & 3.43 & 43 & 32.3 & 1.77 & 1.77 & 2422 \\
\hline 1636 & 66.8 & 15.8 & 13.8 & 70.4 & 3.73 & 53 & 30.1 & 0.44 & 0.89 & 5575 \\
\hline 1642 & 54.9 & 27.1 & 16.1 & 56.8 & 3.68 & 47 & 33.3 & 4.69 & 2.82 & 1159 \\
\hline 1648 & 69.6 & 33.6 & 13.8 & 52.6 & 3.9 & 61 & 26.3 & 1.38 & 0.46 & 4260 \\
\hline 1654 & 44.9 & 29.2 & 15.6 & 55.2 & 3.79 & 55 & 22.7 & 16.91 & 9.66 & 271 \\
\hline 1660 & 49.8 & 20.9 & 20 & 59.1 & 3.5 & 42 & 44.2 & 1.38 & 1.84 & 2625 \\
\hline 1666 & 46.9 & 21.4 & 9.2 & 69.4 & 3.32 & 38 & 12.6 & 25.12 & 7.73 & 202 \\
\hline 1672 & 60.8 & 25.2 & 28.7 & 46.1 & 3.56 & 44 & 27.6 & 2.16 & 3.88 & 1553 \\
\hline 1678 & 60.9 & 22.4 & 24.8 & 52.8 & 3.57 & 45 & 23.8 & 1.98 & 6.93 & 968 \\
\hline 1684 & 64.7 & 25.8 & 22 & 52.3 & 3.67 & 49 & 25 & 0.49 & 4.41 & 1764 \\
\hline 1690 & 64.5 & 26 & 13 & 61 & 3.16 & 27 & 25 & 2.42 & 4.03 & 1289 \\
\hline 1696 & 60.6 & 26.6 & 24.2 & 49.2 & 3.7 & 50 & 34.9 & 0.49 & 2.96 & 2450 \\
\hline 1702 & 58.2 & 39.3 & 20.5 & 40.2 & 3.61 & 48 & 24.1 & 3.85 & 10.6 & 574 \\
\hline 1708 & 71.9 & 44.3 & 15.7 & 40 & 3.72 & 53 & 15.8 & 3.94 & 5.91 & 871 \\
\hline 1714 & 66.0 & 22 & 23.4 & 54.6 & 3.62 & 48 & 23.6 & 8.96 & 0.47 & 914 \\
\hline 1720 & 64.5 & 28.6 & 18.1 & 53.4 & 3.71 & 55 & 29.1 & 5.42 & 0.98 & 1357 \\
\hline 1726 & 59.2 & 20.5 & 23 & 56.6 & 3.55 & 44 & 31.1 & 3.88 & 1.5 & 1625 \\
\hline 1732 & 61.2 & 23.8 & 15.1 & 61.1 & 3.6 & 46 & 33.5 & 2.91 & 1.5 & 1970 \\
\hline 1738 & 65.2 & 25.2 & 13.9 & 60.9 & 3.54 & 46 & 28.4 & 1.99 & 2.5 & 1920 \\
\hline 1744 & 51.0 & 21.6 & 3.9 & 74.5 & 3.22 & 35 & 43 & 1.5 & 2.5 & 2133 \\
\hline 1750 & 28.4 & 1.5 & 1 & 97.5 & 1.48 & 6 & 68.7 & 2.99 & 0 & 2167 \\
\hline
\end{tabular}




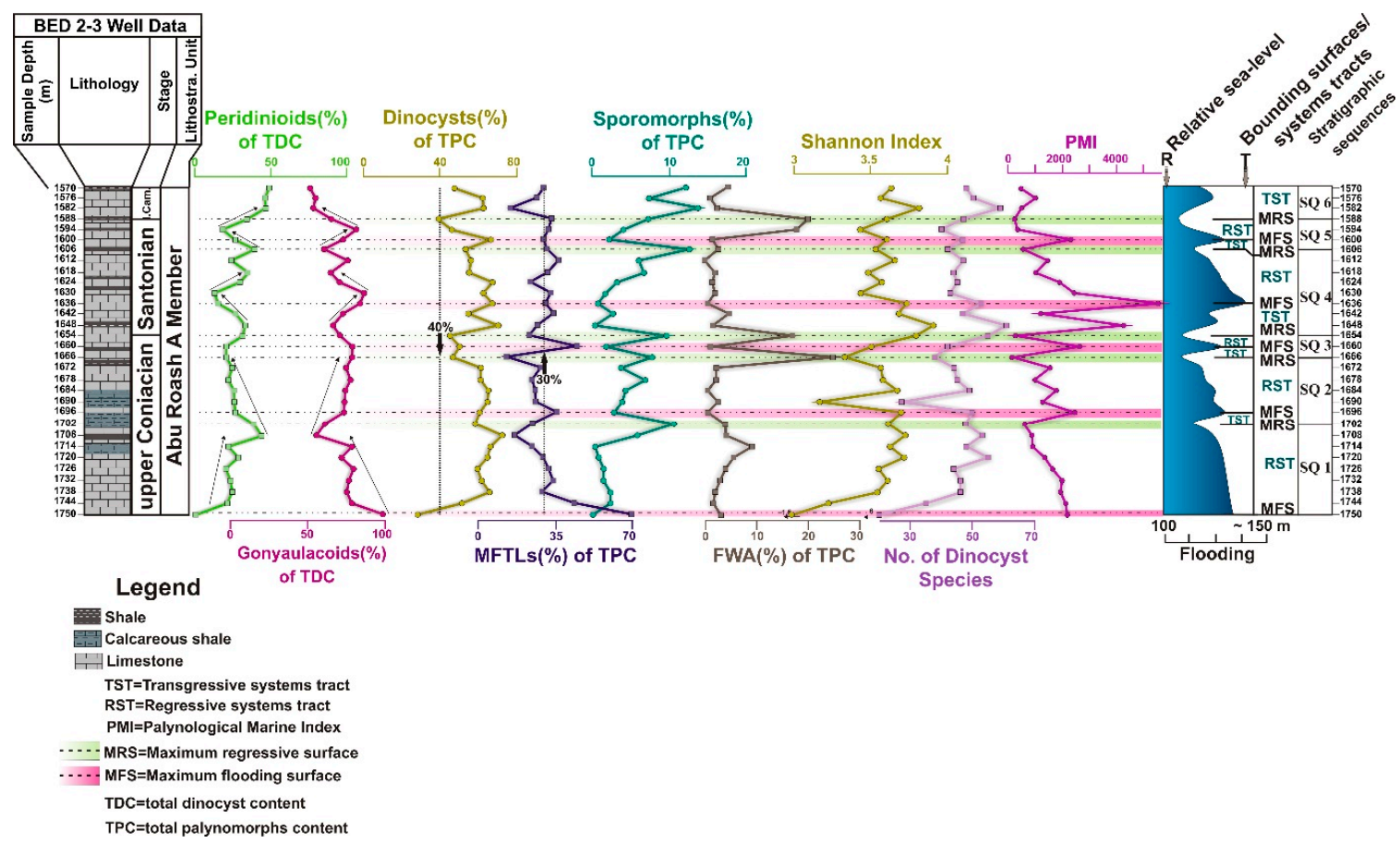

Figure 4. Stratigraphic vertical distribution of various palynomorphs components and dinocyst diversity used to construct transgressive-regressive trends of the relative sea level as well as the stratigraphic sequences and systems tracts of the Abu Roash A Member.

In most ecological approaches, the SDI values range between 1.5 and 3.5 and rarely, they are greater than 4 [37] (Table 1). The dinocyst diversity based on the SDI ranged between 3.2 and 3.9 with an average of 3.6, except for one sample at $1750 \mathrm{~m}$ was consistent with a low diversity (1.48) due to a moderate palynomorphs content (Figure 4). The values of the SDI considerably increase with increasing the richness and evenness of a dinocyst community. The number of dinocyst species was also considered for further consistency of dinocyst SDI (Supplementary Table S1). The number of dinocyst species was generally high (27-61, avg. 4.6 species/sample) and only the sample at $1750 \mathrm{~m}$ contained a low number of dinocyst species (6 species).

Sea level reconstructions of the Abu Roash A Member are carried out based on the richness of marine phytoplankton (e.g., percentages of dinocysts, prasinophytes, acritarchs, and microforaminiferal test linings [MFTLs]) versus terrestrially-derived palynomorphs (percentages of spores, pollen grains, and FWA). The most important dinocyst categories that were considered for sea level reconstruction in this study are represented in the skolochorate (Florentinia, Oligosphaeridium, Surculosphaeridium, Hystrichodinium, Hystrichosphaeridium, Pervosphaeridium, Coronifera, and Kleithriasphaeridium groups) versus peridinioid dinocysts (Subtilisphaera, Chatangiella, Satyrodinium, Palaeohystrichophora, Isabelidinium, Trithyrodinium, Eurydinium, Alterbidinium, and Spinidinium groups). The palynological marine index (PMI) was also calculated using the formula [PMI= (marine palynomorphs/terrestrial palynomorphs +1$) \times 100$ ]. It was relatively high throughout the studied succession (5575-201.5, Figure 4). Based on the above contents of different palynomorphs categories and PMI (Figure 4), the relative sea level for the studied succession in the Abu Gharadig Basin was constructed and subdivided into four complete third-order transgressive-regressive sequences (sequence (SQ) 2-5) and two incomplete ones (SQ1 and SQ6).

\subsection{Elemental Geochemistry}

Bulk geochemical composition of the Abu Roash A Member was dominated by a high content of $\mathrm{CaCO}_{3}\left(46.8-87.4\right.$, avg. 69.8 wt.\%) and moderate to low content of $\mathrm{SiO}_{2}(0-23.5$, avg. 12 wt.\%) 
and $\mathrm{Al}_{2} \mathrm{O}_{3}\left(0.6-4.7\right.$, avg. 3 wt.\%, Figure 5, Table 2). The $\mathrm{CaCO}_{3}$ profile displayed a typically inverse relationship to $\mathrm{Al}(r=-0.91, p<0.01, n=28$, not shown). In contrast, a strong relationship between $\mathrm{Al}$ and $\mathrm{Si}$ was indicated $(r=0.84, p<0.01, n=28$, not shown). Additionally, varied concentrations of Ti (0.1-0.4, avg. 0.2 wt.\%), Zr (31-181, avg. 104 ppm), and the Ti/Al (0.09-1.3, avg. 0.23) and Zr/Al ratios (33-167, avg. 75, Figure 5, Table 2) were reported. A strong linear relationship was reported between $\mathrm{Al}$ and $\mathrm{Ti}(r=0.84, p<0.01, n=25$, Supplementary Table S4), except for the lowest part of the study succession (1738-1750 m), while a moderate correlation $(r=0.40, p<0.035, n=28$, not shown) was reported between $\mathrm{Al}$ and $\mathrm{Zr}$. The Mn profile showed considerable fluctuation within the studied succession (201-347, avg. 266 ppm). The Sr/Ca ratio ranged between 33 and 20, with an average of 25 (Figure 5, Table 1).

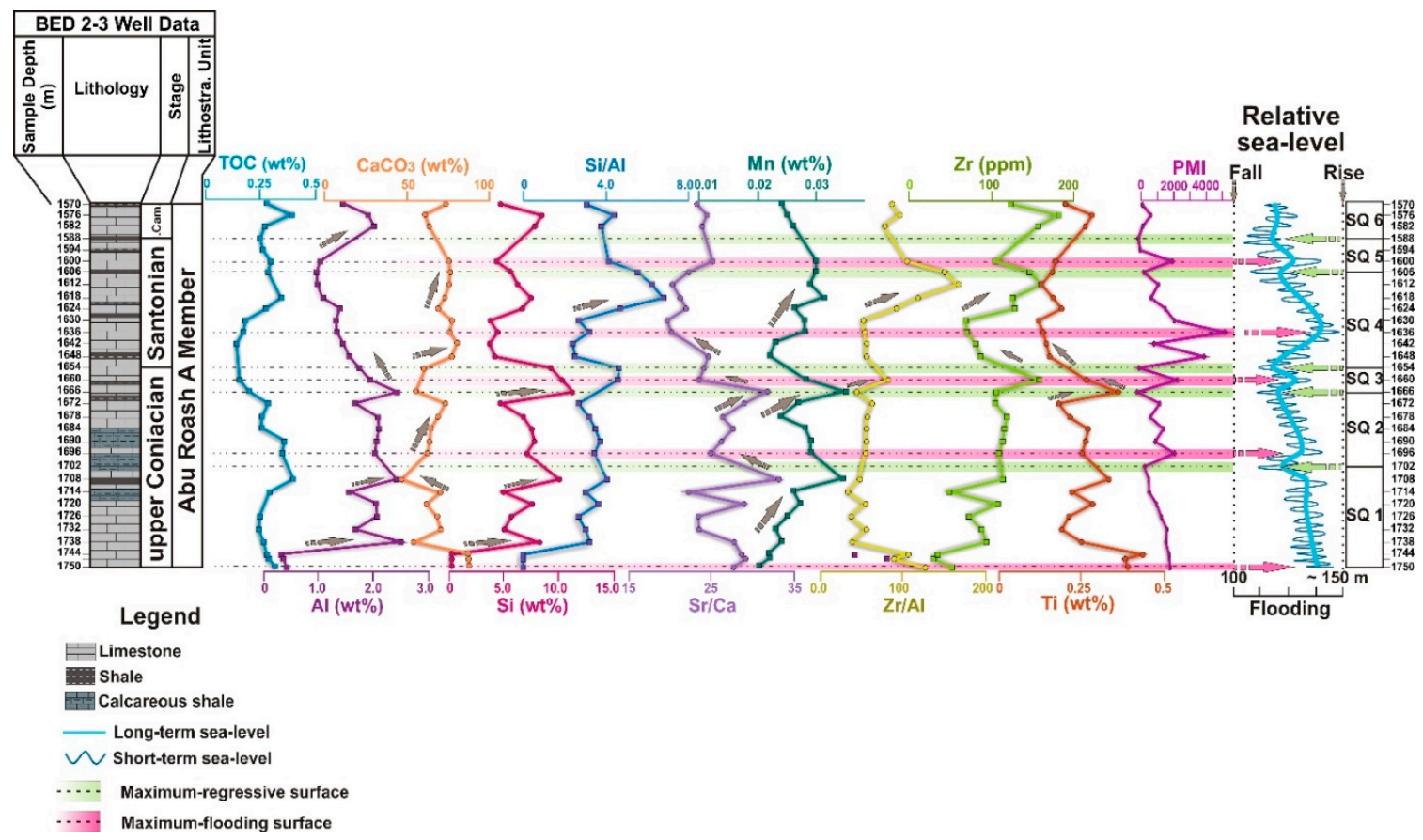

Figure 5. Chemostratigraphic distribution of $\mathrm{TOC}$ (wt.\%), $\mathrm{CaCO}_{3}$, contents of various major and trace elements and ratios, and the palynological marine index (PMI) of the Abu Roash A Member used to construct major/minor transgressive-regressive trends of the relative sea level as well as bounding stratigraphic sequences.

\subsection{Isotope Geochemistry}

Bulk carbonate oxygen $\left(\delta^{18} \mathrm{O}_{\text {carb }}\right)$ and carbon $\left(\delta^{13} \mathrm{C}_{\text {carb }}\right)$ isotope profiles and their assessment for burial diagenesis are illustrated in Figures 6 and 7 and Supplementary Table S3. Within the studied succession, the $\delta^{18} \mathrm{O}_{\text {carb }}$ and $\delta^{13} \mathrm{C}_{\text {carb }}$ values exhibit successive oscillations during the late Coniacian towards the earliest Campanian. Through the upper Coniacian deposits, the $\delta^{13} \mathrm{C}_{\text {carb }}$ values ranged between $1.08 \%$ ond $2.1 \%$ o (avg. 1.61\%o), where lowest values between $1.08 \%$ ond $1.24 \%$ o were recorded at depths of $1708-1666 \mathrm{~m}$. Relatively higher average values of the $\delta^{13} \mathrm{C}_{\text {carb }}$ were reported within the Santonian-lowermost Campanian deposits that reached to $2.20 \%$ ond $2.25 \%$, respectively. Highest values of the $\delta^{13} \mathrm{C}_{\text {carb }}$ of positive trends of $2.71 \%$ and $2.67 \%$ o at depths of 1648 and $1612 \mathrm{~m}$, respectively, were recorded during the Santonian. The $\delta^{18} \mathrm{O}_{\text {carb }}$ values varied and ranged from $-2.88 \%$ to $-3.61 \%$ oVPDB (avg. $-3.16 \%$ ) during the late Coniacian (Figure 7). During the Santonian to earlier most Campanian, the $\delta^{18} \mathrm{O}_{\text {carb }}$ values ranged between $-3.39 \%$ and $-3.06 \%$ o (avg. $-3.19 \%$ o), whereby consequent negative to positive trends were reported, respectively (Figure 7). 
Table 2. Quantitative composition of total organic carbon (TOC), $\mathrm{CaCO}_{3}$, contents of specific major and trace elements and ratios of the studied succession from the BED 2-3 well. NA = not analyzed, $<$ DL = below detection limit.

\begin{tabular}{|c|c|c|c|c|c|c|c|c|c|c|c|c|}
\hline Depth (M) & TOC (wt.\%) & $\mathrm{CaCO}_{3}$ (wt.\%) & $\mathrm{Al}$ (wt.\%) & Si (wt.\%) & $\mathrm{Sr} / \mathrm{Ca}$ & Ba (ppm) & $\mathrm{Zr}(\mathrm{ppm})$ & Mn (wt.\%) & $\mathrm{Zn}$ (ppm) & $\mathrm{Si} / \mathrm{Al}$ & Ti/Al & $\mathrm{Zr} / \mathrm{Al}$ \\
\hline 1570 & 0.28 & 73.8 & 1.43 & 4.36 & 23.1 & 400 & 123 & 0.024 & 39 & 3.05 & 0.14 & 86 \\
\hline 1576 & 0.39 & 60.4 & 1.88 & 8.18 & 24.5 & 570 & 181 & 0.025 & 52 & 4.35 & 0.15 & 96.3 \\
\hline 1582 & 0.27 & 62.9 & 2.01 & 7.58 & 23.8 & 680 & 156 & 0.026 & 44 & 3.77 & 0.13 & 77.6 \\
\hline 1588 & 0.25 & NA & NA & NA & NA & NA & NA & NA & NA & NA & NA & NA \\
\hline 1594 & 0.26 & NA & NA & NA & NA & NA & NA & NA & NA & NA & NA & NA \\
\hline 1600 & 0.3 & 75.4 & 1 & 4.1 & 25.1 & 240 & 105 & 0.03 & 27 & 4.1 & 0.17 & 105 \\
\hline 1606 & 0.29 & 75.9 & 0.97 & 5.34 & 22.2 & 280 & 146 & 0.03 & 35 & 5.51 & 0.16 & 150.5 \\
\hline 1612 & NA & 75.7 & 0.96 & 5.92 & 20.2 & 320 & 160 & 0.029 & 39 & 6.17 & 0.13 & 166.7 \\
\hline 1618 & 0.346 & 72.8 & 1.06 & 7.19 & 21.2 & 230 & 126 & 0.031 & 31 & 6.78 & 0.15 & 118.9 \\
\hline 1624 & 0.28 & 69.4 & 1.39 & 6.41 & 21.9 & 190 & 128 & 0.026 & 37 & 4.61 & 0.14 & 92.1 \\
\hline 1630 & 0.19 & 77.3 & 1.31 & 3.58 & 19.7 & 300 & 69 & 0.028 & 49 & 2.73 & 0.09 & 52.7 \\
\hline 1636 & 0.18 & 76.4 & 1.33 & 4.15 & 20.1 & 296 & 70 & 0.028 & 43 & 3.12 & 0.1 & 52.6 \\
\hline 1642 & 0.15 & 79.3 & 1.45 & 3.47 & 22.4 & 273 & 81 & 0.023 & 36 & 2.39 & 0.09 & 55.9 \\
\hline 1648 & NA & 77.2 & 1.56 & 3.91 & 24.6 & 260 & 87 & 0.022 & 31 & 2.51 & 0.1 & 55.8 \\
\hline 1660 & 0.16 & 61.1 & 1.92 & 8.87 & 23.6 & 390 & 157 & 0.028 & 52 & 4.62 & 0.13 & 81.8 \\
\hline 1666 & 0.2 & 55.5 & 2.41 & 11 & 31.7 & 310 & 106 & 0.035 & 41 & 4.56 & 0.15 & 44 \\
\hline 1672 & 0.29 & 72.7 & 1.66 & 4.43 & 28.9 & 390 & 105 & 0.027 & 50 & 2.67 & 0.11 & 63.3 \\
\hline 1678 & 0.26 & 68.8 & 2.07 & 6.52 & 26.3 & 230 & 118 & 0.024 & 43 & 3.15 & 0.1 & 57 \\
\hline 1684 & 0.26 & 64.4 & 2.08 & 7.19 & 27.5 & 250 & 116 & 0.028 & 47 & 3.46 & 0.13 & 55.8 \\
\hline 1690 & 0.36 & 63.9 & 2.04 & 7.44 & 26.1 & 320 & 113 & 0.029 & 45 & 3.65 & 0.13 & 55.4 \\
\hline 1696 & 0.35 & 63.1 & 2 & 6.83 & 24.8 & 540 & 109 & 0.029 & 44 & 3.42 & 0.13 & 54.5 \\
\hline 1708 & 0.4 & 46.8 & 2.39 & 9.69 & 33.1 & 260 & 112 & 0.034 & 54 & 4.05 & 0.14 & 46.9 \\
\hline 1714 & 0.29 & 69.3 & 1.57 & 4.7 & 22.2 & 310 & 51 & 0.026 & 28 & 2.99 & 0.14 & 32.5 \\
\hline 1720 & NA & 61.1 & 2.01 & 7.22 & 28.8 & 160 & 107 & 0.027 & 40 & 3.59 & 0.14 & 53.2 \\
\hline 1726 & 0.25 & 67.5 & 2.03 & 5.45 & 23.4 & 160 & 73 & 0.025 & 39 & 2.68 & 0.1 & 36 \\
\hline 1732 & 0.25 & 69.2 & 1.65 & 4.82 & 23.5 & 650 & 88 & 0.023 & 49 & 2.92 & 0.12 & 53.3 \\
\hline 1738 & 0.26 & 54.3 & 2.46 & 7.73 & 27.7 & 410 & 93 & 0.024 & 47 & 3.14 & 0.1 & 37.8 \\
\hline 1744 & 0.27 & 86.2 & 0.33 & $<\mathrm{DL}$ & 28.6 & 604 & 35 & 0.022 & 40 & $<\mathrm{DL}$ & 1.3 & 106.1 \\
\hline 1746 & 0.29 & 86.9 & 0.35 & $<\mathrm{DL}$ & 29.1 & 610 & 31 & 0.022 & 38 & $<\mathrm{DL}$ & 1.52 & 88.6 \\
\hline 1750 & 0.32 & 87.4 & 0.42 & $<\mathrm{DL}$ & 27.6 & 6770 & 53 & 0.02 & 42 & $<\mathrm{DL}$ & 0.94 & 126.2 \\
\hline
\end{tabular}



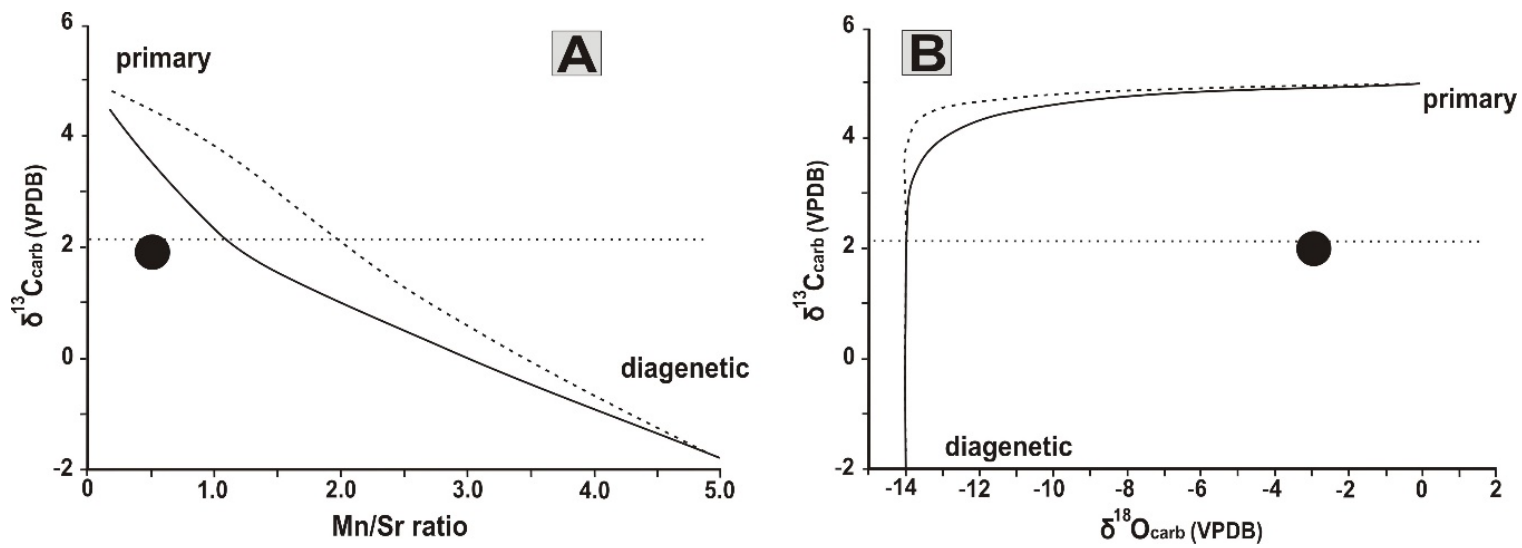

Figure 6. Modeled values to indicate the degree of post-sedimentary diagenetic alteration for the studied samples. (A) $\mathrm{Mn} / \mathrm{Sr}$ ratio versus $\delta^{13} \mathrm{C}_{\text {carb }}$ composition. (B) $\delta^{13} \mathrm{C}_{\text {carb }}$ versus $\delta^{18} \mathrm{O}_{\text {carb }}$ composition. The lines in $\mathrm{A}$ and $\mathrm{B}$ at ca. $2.2 \%$ represent the modern ocean surface water compared to $2 \%$ of Cretaceous Ocean average $\delta^{13} \mathrm{C}$ values. The black circle represents the Abu Roash A Member, whereby all samples plot slightly below and very close to the average $\delta^{13} \mathrm{C}$ values of modern ocean surface water and Cretaceous ocean water, respectively [38].

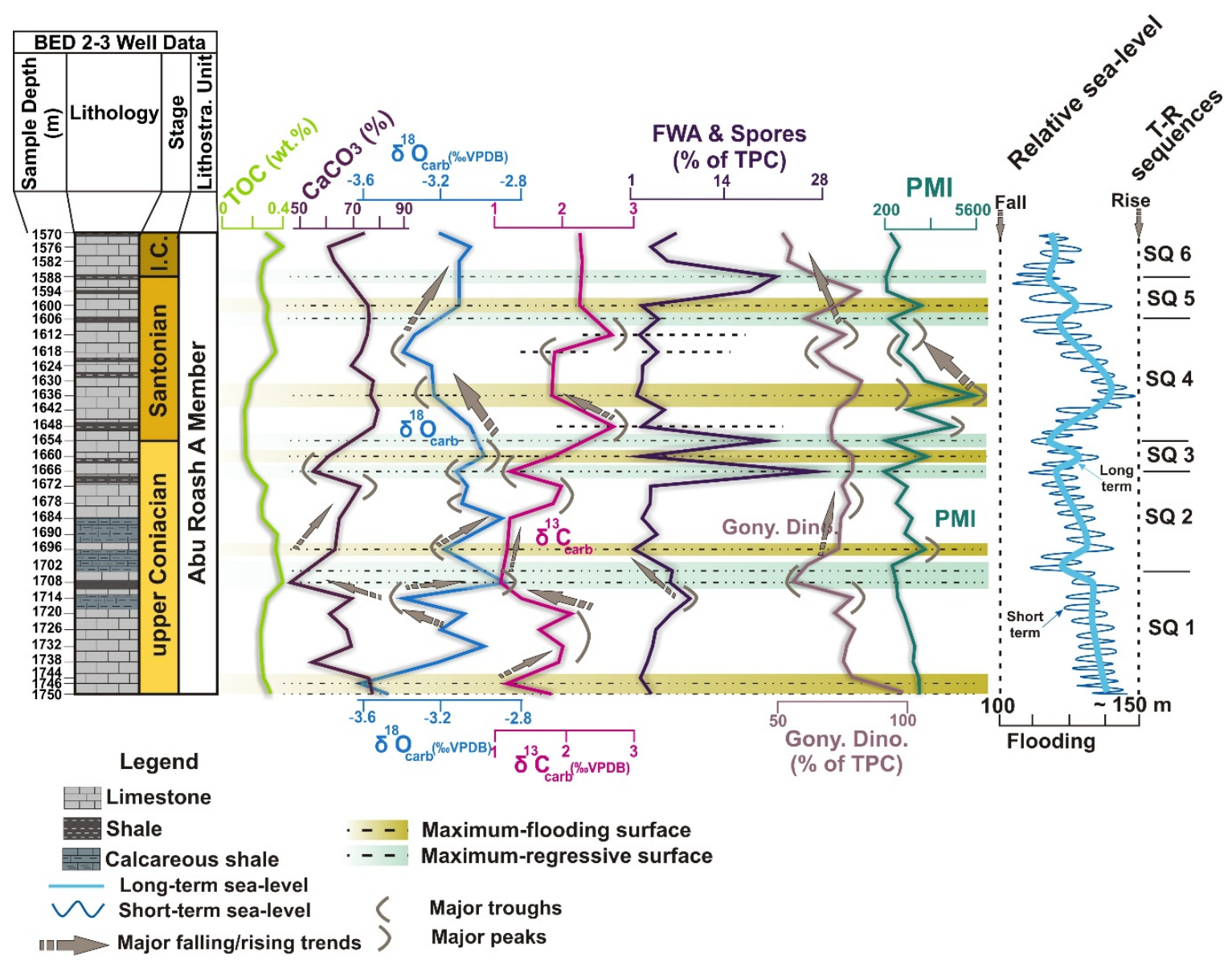

Figure 7. Bulk carbonate stable carbon and oxygen isotope profiles along with specific palynomorphs parameters used to reconstruct the relative sea level during deposition of the Abu Roash A Member. FWA = Freshwater algae, Gony. Dino. = Gonyaulacoid dinocysts, PMI = Palynological marine index. 


\section{Discussion}

\subsection{Palynomorph-Based Sequence Stratigraphy and Sea Level Change}

During the Cretaceous, a global culmination of dinocysts species origination and diversity were partly controlled by eustatic sea-level transgression (Figure 1) [5,6]. This is evidenced by the strong positive correlation between the dinocyst species diversity and the eustatic sea level curve (Figure 1), from their first appearance during the Triassic up to the Cretaceous [2,6]. Modern shelf facies, mainly middle to outer shelf areas as in the studied succession, are characterized by the highest dinocyst richness during a major marine transgression compared to inner shelf as well as slope to basin regions and estuarine areas that contain much lower abundances [39]. Therefore, we deduce that higher dinocyst species diversity is related to periods of predominant high eustatic sea levels, especially transgressive systems tracts (TSTs).

Several dinocyst groups are commonly known to indicate paleoenvironmental and transgressive-regressive phases. For example, the chorate Coronifera, Florentinia, Exochosphaeridium, Oligosphaeridium, and Hystrichodinium groups versus proximo-chorate Spiniferites, Heterosphaeridium, and Downiesphaeridium groups (Supplementary Table S1) [10,11,14,40] were used in this study to reveal the Tethyan sea level changes. The higher percentages of the above chorate dinocyst groups are environmentally tolerant and geographically widespread in areas of middle-outer neritic shelf to open-marine settings, revealing a transgressive phase of sea level [40]. Additionally, the relative abundance of the holocavate peridinioids in the Abu Roash A Member, such as Subtilisphaera Alterbidinium, Isabelidinium, and Chatangiella (Supplementary Table S3) groups, supports a low relative sea level and deposition in high nutrient supply coastal to shallow water environments [8]. These holocavate peridinioid groups represent moderate to low abundances in the current study, but generally their peaks indicate shallower settings of a regressive sea level and deposition of a regressive systems tracts (RST). Similarly, their highest abundances are consistent with the maximum regressive surfaces (MRSs) of relative sea level. Besides, the presence of increased terrestrially derived palynomorphs, such as spores, pollen grains, and FWA, can be explained by higher riverine influx and shallower marine conditions that are typical of a regressive sea level [13,41].

Relative abundances of marine versus terrestrial palynomorphs are widely acknowledged to define the magnitude of transgressive-regressive trends and depositional sequence stratigraphy and systems tracts [5,6,8-14,23]. The PMI was also used to assist in constructing the relative sea level and positioning of bounding surfaces for sequence stratigraphy purposes [42]. The PMI was relatively high, indicating that the entire succession was deposited in a marine environment [42]. Generally, the highest values of the PMI coincided with maximum flooding surfaces (MFSs) in comparison to the lowest values that matched with MRSs.

The TSTs through the Abu Roash A Member are characterized by a gradual increase of the chorate and the proximo-chorate gonyaulacoids compared to the peridinioid dinocysts (Figure 4, Table 1), reinforcing rapidly rising sea level in the southern Tethys, Egypt [2]. The reported high occurrence of Surculosphaeridium longifurcatum [14] and Palaeohystrichophora infusorioides [8] at depths of 1660, 1696, and $1600 \mathrm{~m}$ coincides with MFSs of SQ2, SQ3, and SQ5. Both species thrive in a basinward deeper water, from middle to outer neritic conditions, and correspond to a relative sea level rise of the Tethys Ocean. Our interpretation is supported by a previously documented paleobathymetry for the Abu Gharadig Basin, which was based on foraminiferal assemblages, whereby a 100-200 m rise in sea level occurred during the Coniacian-Santonian that drastically increased to greater than $200 \mathrm{~m}$ during the Campanian [33]. Yet, the MFTLs have high content indicating a prolonged major transgression of the sea level (Figure 4, Table 1) [9], thus their maximum peaks have been used as reliable indicators of the MFSs. However, due to the fluctuating neritic conditions during deposition of this succession, MFTLs showed considerable variability in abundance within the TSTs. The PMI rapidly rose throughout the TSTs up to maxima at the MFSs, for example: peak values of approximately $2160,2450,2625,5575$, and 2310 at depths of 1750, 1696, 1660, 1636, and $1600 \mathrm{~m}$, respectively. 
The dinocyst diversity increased within the TSTs up to maxima at the MFSs as in the SQ2-SQ5, respectively (Figure 4, Table 1). This is related to increased sea level [2], which led to increased environmentally controlled shelf stability and ecological niches for abundant phytoplankton communities. This interpretation is supported by the conclusions of [6], who indicated that a drastic increase in dinocyst diversity ranged from 315 species during the Coniacian to 397 and 501 in the Santonian and Campanian, respectively, and was strongly paralleled by a sea level rise. Here, the calculated dinocyst diversity using the SDI is strongly coincident with the counted number of the documented dinocyst species (Figure 4) and is in agreement with the results of [6], thus confirming a sea level rise in the southern Tethys, Egypt. The spores and pollen grains have lower abundances through the TSTs than in the RSTs, supporting distal deposition and widespread transgression of the Tethys with a relatively low terrestrial input $[9,43]$ (Figure 4, Table 1). The sporomorphs content was dominated by pollen grains and represented by Aruacariacites sp., Spheripollenites sp., Inaperturopollenites sp., Classopollis sp., Foveotricolpites sp., and Tricolpites spp., while the pteridophytic spore content was very low and dominated by Cyathidites australis and Deltoidospora minor (Supplementary Table S1). The predominance of the sphaeromorphs pollen compared to low spore content in total palynomorphs indicates deposition in a relatively distal offshore, far from terrigenous influx during a prolonged marine transgression $[9,43]$.

On the other hand, the RSTs were characterized by a gradual increase in the peridinioid dinocysts (Figure 4). However, almost all gonyaulacoid groups, previously mentioned as indicating a widespread transgression, deceased slightly within the RST and at the MRS in particular. This was supported by an inverse relationship exhibited between the gonyaulacoid and peridinioids groups $(r=1, p<0.01$, $n=31$, not shown) in parallel with sea level oscillations (Figure 4). The relative abundance of the FWA has been widely used as a reliable palynomorph proxy for proximal nearshore to shallow water settings $[43,44]$ and during regression events of the relative sea level, especially at MRS $[13,45]$. For the studied succession, a slight increase in the FWA was recorded within the RSTs (Table 1), with significant peaks at MRS of sequences SQ2, SQ3, and SQ5. The PMI decreased significantly within the RSTs up to minima at the MRSs, with values estimated by $574.2,201.5,271.4,543.8$, and 264.6 at depths of 1702 , 1666, 1654, 1606, and $1588 \mathrm{~m}$, respectively (Figure 4, Table 1).

Overall, the variations in palynomorphs parameters pointed to a long-term transgression of the Tethys Ocean despite minor, short-term regression phases during the late Coniacian-earliest Campanian. This transgression was accompanied by a global culmination of eustatic sea level. The reconstructed sea level from palynological inferences will be used in the upcoming sections to indicate whether a rigorous relationship exists between palynomorphs parameters and inorganic elemental geochemistry and isotope measurements for robust future sea level change assessment based on these three endmember proxies.

\subsection{Elemental Proxies, Sequences, and Sea Level}

Relative abundances of various major and trace elements and their ratios, including $\mathrm{Si}, \mathrm{Al}, \mathrm{Zr}, \mathrm{Sr}$, $\mathrm{Ca}, \mathrm{Fe}, \mathrm{Ti}$, and $\mathrm{Mn}$, shown in Figure 5 and Table 2, are linked to sea level oscillations and have been shown to vary within a sequence stratigraphic framework [12,18-22]. Thus, we used bulk-geochemical composition to interpret short-term sea level changes and systems tracts. Higher $\mathrm{CaCO}_{3}$ content was consistent with a lower Al concentration especially at depths of 1750, 1696, 1660, 1636, and $1600 \mathrm{~m}$, which is coincident with the MFSs of a basinward marine deposition during a long-term high sea level [12,18-22] (Figure 5, Table 2). In contrast, general trends of Al and Si showed very similar profiles with a strong correlation, which is presumably related to increasing silty/clayey contents during deposition of basinal hemipelagic carbonate sediments during a minor/local regression phase [12]. Peaks in Al (2.4-1.9 wt.\%), Si (8.9-7.9 wt.\%) and Si/Al ratio were noted at depths of 1708 and $1666 \mathrm{~m}$ compared to the drastic decrease of the $\mathrm{CaCO}_{3}$ content that was estimated to be 46.8 and $55.5 \mathrm{wt} . \%$, respectively. This provided an indication of short-term relative sea-level fall and coincided with MRSs 
(Figure 5). Additionally, of note, the geochemical composition at sequence stratigraphic surfaces is in a good agreement with the former inferences from palynological composition and PMI (Figure 4).

Strontium in marine ecosystem has a complex geochemical pattern. The Sr content of pelagic/ hemipelagic carbonates is controlled by seawater chemistry, environmental, and biological/productivity richness factors [46]. Due to the relative abundance of Sr concentration in shallow-water carbonates and carbonates-rich pelagic settings at periods of sea level lowstand, it can be used as a proxy of sea level reconstruction especially at standardization against Ca [47]. The Sr/Ca ratio has been used in several studies to infer major trends of relative sea level, whereby lower $\mathrm{Sr} / \mathrm{Ca}$ ratios are consistent with a transgression phase of relative sea level and vice versa $[19,22,47]$. The overall trend of the $\mathrm{Sr} / \mathrm{Ca}$ ratio (Figure 5) fluctuated considerably and rose through the RSTs with two peaks at the MRSs (1708, $1606 \mathrm{~m}$ ), which infers a short-term marine regression through the study interval. Besides, the Sr/Ca ratio attained minimum values at MFSs of the SQ2-SQ5, supporting a long-term high sea level of the Tethys (Figure 5, Table 2).

An increase in terrestrial siliciclastic input leads to a relative increase of detrital/clay-mineral associated elements such as $\mathrm{Si}, \mathrm{Al}, \mathrm{Ti}, \mathrm{K}$, and $\mathrm{Zr}$ and consequently increases ratios such as Ti/Al, K/Al, and $\mathrm{Zr} / \mathrm{Al}$ [22]. Nonetheless, Ti and $\mathrm{Zr}$ exist mainly in zircon and other heavy minerals. Relating to sea level change and sequence stratigraphy, whereby higher values of $\mathrm{Ti} / \mathrm{Al}$ and $\mathrm{Zr} / \mathrm{Al}$ ratios can coincide with a relative sea-level fall and MRS during deposition [12,18,22]. The observed strong and moderate relationships between $\mathrm{Ti}$ and $\mathrm{Zr}$ versus $\mathrm{Al}$, respectively, might be attributed to a slight increase of clay-rich sediments with higher heavy mineral content during transgressive episodes of relative sea level [18]. At MRSs of the SQ1-SQ4, rising Ti (0.2-0.4 wt.\%) and $\mathrm{Zr}$ (106-146 ppm) concentrations along with $\mathrm{Al}$ (1-2.4 wt.\%) and Si (5.3-11 wt.\%) indicate deposition during enhanced terrigenous input of siliciclastics-heavy mineral rich deposits, as inferred from the calcareous shale streaks intercalation at these horizons. The former interpretation is in a good agreement with a relatively high abundance of the FWA (up to 10.6 and $12.7 \%$ of TPC). In contrast, this was followed by a noticeable decrease of the Ti and Al contents at the MFSs of the SQ2-SQ4 versus a drastic rise in $\mathrm{CaCO}_{3}$ content (up to 76.4 and $87.4 \mathrm{wt} . \%$ ), which is attributed to the independent concentration of heavy minerals from hemipelagic carbonate accumulation and was combined only with clay-rich sediments [12,18]. Yet, this was supplemented by prominent peak abundances of gonyaulacoid dinoflagellates and low to absent FWA content (Figure 4, Table 1). This was supported by very low to absent siliciclastic-associated $\mathrm{K}$ concentration that likely was below detection limits (Table 2).

The Mn content in pelagic-hemipelagic sediments is controlled by the terrigenous detrital input of siliciclastics. Like the Sr habitat, Mn is characterized by a complex marine geochemistry. The relationship between Mn marine geochemistry and its variation with respect to sedimentation rates and biogenic versus detrital supply was discussed by [18]. Increased Mn content coincides with sea level transgression and vice versa [12,22]. For the studied interval, moderate concentration of Mn reinforces a long-term sea-level highstand during deposition. However, a gradual increasing trend of Mn was noticed along with Ti through the RSTs with a peak abundance at the MRS of the SQ2 at depth of $1666 \mathrm{~m}$. At this interval, there was also a drastic decrease of carbonate content (from 72.7 to $55.5 \mathrm{wt}$ \%) versus an increase in detrital/clay minerals content of Si (from 4.4 to $11 \mathrm{wt} \%$ ) and $\mathrm{Al}$ (from 1.7 to $2.4 \mathrm{wt}$ \%). In this case, Mn content appears to be associated with siliciclastic detrital/clay minerals [18]. Our interpretation is also supported by a strong correlation observed between Mn and Si $(r=0.7, p<0.01, n=28$, not shown) and Mn and Al at most parts of the succession $(r=0.72$, $p<0.01, n=20$, not shown) except for specific intervals that showed less similarities (1600-1642 m). $\mathrm{Mn}$, in contrast, showed a negative relationship with carbonates $(r=-0.56, p<0.01, n=28$, not shown). Le Callonnec et al. [21] indicated the complexity of Mn geochemistry, whereby Mn can be associated with OM-rich facies, pelagic-hemipelagic carbonates, and clay-rich sediments. Such an indication may explain the complex habitat of Mn and care should be taken while interpreting Mn profiles. 


\subsection{Stable Isotopes, Diagenetic Overprint, and Changes of Sea Level}

One of the objectives of this study is to determine whether the stable isotope profiles could be used, along with palynomorphs composition, for sea level changes [22,48]. The $\delta^{13} \mathrm{C}$ of bulk hemipelagic carbonates reflects the isotope signature of past seawater during deposition. Although $\delta^{13} \mathrm{C}_{\text {carb }}$ is sensitive to a number of factors, such as fluviatile input during deposition, post-depositional diagenetic alterations, and dissolved inorganic carbon of the ambient water, etc. [25], it can be used as a proxy for past changes of sea level $[19,20,22,49]$. Chemical alteration during carbonate diagenesis can be assessed through the relationship between bulk carbonate $\delta^{13} \mathrm{C}$ and $\delta^{18} \mathrm{O}$ along with $\mathrm{Mn} / \mathrm{Sr}$ ratios. The hemipelagic carbonate deposits of the Abu Roash A Member were deposited during oxic intermittent with slight dysoxic conditions [23], whereby the effect of redox-driven diagenesis on $\delta^{13} \mathrm{C}_{\text {carb }}$ signals is expected to be insignificant compared to the $\delta^{18} \mathrm{O}_{\text {carb }}$ [26]. Previous studies have indicated that oxygen isotopes are more sensitive to burial, meteoric alterations and environmental processes than carbon isotopes $[24,25,38,50]$, especially in pelagic-hemipelagic carbonates. The relationship between the $\delta^{18} \mathrm{O}_{\text {carb }}$ and $\delta^{13} \mathrm{C}_{\text {carb }}$ reading indicated insignificant correlation for the studied succession $(r=0.05, p=0.82, n=23$, see Supplementary Table S2), which is inconsistent with a strong meteoric and/or burial diagenetic resetting of the $\delta^{13} C_{\text {carb values }}[26,50]$.

Further confirmation was deduced from a modeled distribution of $\mathrm{Mn} / \mathrm{Sr}$, and oxygen and carbon isotopes of Jacobsen and Kaufman [38] (Figure 6A,B). Carbon versus oxygen isotope readings plot below the modeled concentrations due to the $\delta^{13} \mathrm{C}$ composition of the Cretaceous seawater that averaged $2 \%$ (Figure 6A) [51] and is very close to the modern ocean surface waters that is slightly above 2\%o [52]. Additionally, the average values of the $\mathrm{Mn} / \mathrm{Sr}$ ratio versus $\delta^{13} \mathrm{C}_{\text {carb }}$ readings very close to the line of a closed system that exhibits a rapid cementation of low-Mg calcite during the early diagenesis phase (Figure 6B), suggesting a reduced diagenetic overprint of the studied samples [38]. Furthermore, the very low organic matter content of the Abu Roash A Member (TOC $<0.5$ wt.\%) would reinforce that post-depositional alteration of carbonate deposition and associated isotope fractionation during organic matter degradation is highly unlikely. Nevertheless, Jenkyns et al. [50] showed that a sudden shift in $\delta^{18} \mathrm{O}_{\text {carb }}$ of greater than $0.5 \%$ intra-sample variability within the pelagic English Chalk was presumably due to a signal of diagenetic alteration and/or potential error. Although this assumption is not indicative of strong diagenesis, a shift in the $\delta^{18} \mathrm{O}_{\text {carb }}$ profile by ca. $0.5 \%$ (from $-3.39 \%$ o to $-2.88 \%$ ) at depths of 1714-1708 $\mathrm{m}$ (Figure 7) is assumed to infer an original isotopic signal. This interpretation is based on the abundance of autochthonous gonyaulacoids that drastically decreased from $78 \%$ to $55.7 \%$ of TPC consistent with the former $\delta^{18} \mathrm{O}_{\text {carb }}$ positive trend for the same intervals (Figure 7 , Supplementary Table S2). Both the $\delta^{18} \mathrm{O}_{\text {carb }}$ and gonyaulacoid dinocyst records are in agreement with a short-term fall of sea level and a change in paleoenvironment from middle neritic to distal inner neritic, respectively [23].

Specific groups of the reported palynomorphs such as gonyaulacoid dinocysts versus the terrestrially derived FWA and pteridophyte spores and PMI were used to calibrate $\delta^{13} C_{\text {carb }}$ excursions with their relative abundances and verify whether $\delta^{13} \mathrm{C}_{\mathrm{carb}}$ can be a reliable indicator for sea level reconstructions (Figure 7). The gonyaulacoid dinocysts are much preferred because they represent a preserved autochthonous assemblage and indicate deepening sea-level trends due to their preference of environmental settings towards deeper shelf, mainly middle-outer neritic, and open oceanic environments $[11,23,40]$.

During the late Coniacian (1750-1654 m, Figure 7), the $\delta^{13} \mathrm{C}_{\text {carb }}$ profile in the studied succession showed a slightly similar trend to that of the gonyaulacoid dinocyst record and exhibits a moderate relationship ( $r=0.42, p<0.01, n=14$, not shown) throughout the SQ1-SQ3. This was accompanied by four peaks in the $\delta^{13} C_{\text {carb }}$ profile at depths of 1738, 1720, 1678, and $1672 \mathrm{~m}$ within the SQ1-SQ3, which were reported through their TSTs and at MFSs (Figure 7). Therefore, these peaks corresponded to a relative sea level high (Figure 7). Additionally, two troughs were reported in both profiles of $\delta^{13} C_{\text {carb }}$ and gonyaulacoid dinocyst at depths of 1666 and $1708 \mathrm{~m}$. These were consistent with two peaks of the FWA-spores curve, which coincided with short-term regression of relative sea level and the sequence 
boundaries of the SQ1 and SQ2, respectively (Figure 7). Most interestingly, Jarvis et al. [20] showed similar behavior from the central Bohemian Cretaceous Basin in the Czech Republic and indicated that more than $70 \%$ of short-term transgressive episodes of their Turonian-Coniacian interval matched well with the $\delta^{13} \mathrm{C}_{\text {carb }}$ peaks compared to ca. $50 \%$ of the regressive phases that coincided with $\delta^{13} \mathrm{C}_{\text {carb }}$ minimum values. The observed moderate correlation with a relatively similar patterns between $\delta^{13} \mathrm{C}_{\mathrm{carb}}$ and palynomorph records and rising/falling sea level can point to two outstanding inferences: (1) $\delta^{13} C_{\text {carb }}$ profile represents original signals that are less prone to diagenesis at this time [24,49]; and (2) $\delta^{13} C_{c a r b}$ excursions can be a good proxy for sea level reconstructions when exhibiting original seawater signals, whereby positive trends might be consistent with sea level rise and vice versa. However, the relationship between $\delta^{13} \mathrm{C}$ and sea level is not simple and straightforward because various local to regional processes can modulate the carbon cycle with some regional differences in $\delta^{13} \mathrm{C}$ [25].

During the Santonian, the $\delta^{13} \mathrm{C}_{\text {carb }}$ exhibited a positive upward trend that matched, to some extent, with a drastic increase of the gonyaulacoid dinocyst content up to the MFS of SQ4. This was followed by a slight negative trend of the $\delta^{13} \mathrm{C}_{\text {carb }}$ that was in agreement with a decline in the gonyaulacoid dinocyst content (from 1630 to $1618 \mathrm{~m}$, Figure 7) through the RST sediments of SQ4. Despite a slight fall in the gonyaulacoid dinocysts profile during the earliermost Campanian compared to a prominent peak of the FWA-pteridophytic spores profile, the $\delta^{13} \mathrm{C}_{\text {carb }}$ record remained relatively constant (ca. 2.2\%o, Figure 7). This situation is likely linked to local environmental processes, whereby a slight fall in sea level would trigger reworking and basinward transport of terrestrial mineralogical/OM into the pelagic system 22, 25]. At the same time, a drastic upward decrease of the carbonate content was consistent with the former settings.

Overall, we deduce that positive $\delta^{13} \mathrm{C}_{\text {carb }}$ trends were consistent with excess gonyaulacoid dinocysts at several intervals corresponding to transgressive phases of the Tethys. In contrast, the negative $\delta^{13} C_{c a r b}$ trends matched with FWA-spores peaks, indicating a regressive sea level and enhanced terrestrial/riverine fluxes. However, specific uncertainties of $\delta^{13} C_{\text {carb }}$ records are probably attributed to the enhanced effect of physical, mineralogical or post-depositional processes.

On the other hand, negative $\delta^{18} \mathrm{O}_{\text {carb }}$ trends infer periods of warming and relative sea-level rise and vice versa as is the case for the interglacial-glacial periods $[4,22,53]$. However, this relationship is not always straightforward during greenhouse-controlled sea level cycles [54]. Here, we compared the $\delta^{18} \mathrm{O}_{\text {carb }}$ excursions with palynomorphs compositions (i.e., gonyaulacoid dinocyst versus FWA-spores contents) as a proxy for sea level changes.

Within the upper Coniacian strata, the $\delta^{18} \mathrm{O}_{\text {carb }}$ profile showed a weak correlation with the gonyaulacoid dinocyst profile $(r=0.25, p<0.001, n=14)$ compared to the $\delta^{13} C_{\text {carb }}$ curves. Of note, the $\delta^{18} \mathrm{O}_{\text {carb }}$ curve reflects a slightly inverse trend compared to the gonyaulacoid dinocyst profile with short to long amplitudes of peaks and troughs, as illustrated in several intervals at depths of 1726, 1720, $1714,1708,1696,1684,1678,1672$, and $1666 \mathrm{~m}$. Thus, the negative $\delta^{18} \mathrm{O}_{\text {carb }}$ trends matched, in part, with a gonyaulacoid dinocyst increase and are indicative of rising sea level [48]. A clear example can be seen at depths from 1732 to $1714 \mathrm{~m}$, where a negative $\delta^{18} \mathrm{O}_{\text {carb }}$ trend (from $-2.99 \%$ o to $-3.39 \%$ ) was consistent with an upward increase of the gonyaulacoid dinocysts (from ca. 74 to $78 \%$ of TPC) and coincided with a gradual sea level fall through SQ1. Most prominently, a positive $\delta^{18} \mathrm{O}_{\text {carb }}$ trend (from $-3.39 \%$ o to $-2.89 \%$ ) versus a drastic fall in gonyaulacoid dinocyst (from ca. $78 \%$ to $56 \%$ of TPC) indicates a MRS at a depth of $1708 \mathrm{~m}$. This was followed by a negative $\delta^{18} \mathrm{O}_{\text {carb }}$ trend (of up to ca. $-3.2 \%$ ) at a depth of $1696 \mathrm{~m}$ compared to a drastic increase of gonyaulacoids (from $56 \%$ to $73.4 \%$ of TPC) and to a decrease in FWA-spores content (from $10 \%$ to $0.7 \%$ of TPC), which coincided with the MFS of SQ2. The same holds true at specific intervals through SQ3 and SQ4, where negative $\delta^{18} \mathrm{O}_{\text {carb }}$ trends (of up to ca. $-3.0 \%$ ond $-3.4 \%$ at depths of 1660 and $1636 \mathrm{~m}$, respectively) coincided with TSTs and MFS, which was reinforced by typical trends of rising gonyaulacoid dinocysts $(79.1 \%$ and $84.2 \%$ of TPC) and falling FWA-spore profiles (from as high as $27 \%$ to less than $1 \%$ of TPC, Figure 7 ). From the upper Santonian to the lowermost Campanian, the $\delta^{18} \mathrm{O}_{\text {carb }}$ profile showed a minor positive 
trend (from $-3.39 \%$ o to $-3.06 \%$ ) at depths from 1618 to $1576 \mathrm{~m}$ and coincided with a drastic rise in the FWA-spore (from $2.4 \%$ to $19.9 \%$ of TPC) and fall in gonyaulacoid dinocyst contents (from $81 \%$ to $53 \%$ of TPC), reinforcing a relative fall in sea level. Even though $\delta^{18} \mathrm{O}$ could show, to some extent, inverse patterns with the palynomorphs composition, an absence of correlations became apparent between both variables and such pattern is not always existing. Therefore, $\delta^{18} \mathrm{O}$ should be used only as a proxy indicator for the long-term sea level changes compared to short-term fluctuations.

\subsection{Link between Sea Level and Climate Changes}

Eustatic sea level changes are generally related to several factors including tectonics, continental rise and subsidence, and climate shifts [2,20]. Large continental ice volumes through periods of the Earth history versus the recently tested notion of climatically-controlled groundwater storage and release, are still a matter of debate whether they acted as reservoirs for the ocean water volume growth rates and the accompanied short-term eustatic sea level change [3] and references therein. The assumption of eustatic sea-level rise in mid-Cretaceous due to aquifer-eustasy rather than glacio-eustasy is commonly disregarded because of the uncertainties of water estimates released from groundwater aquifer reservoirs as well as the minor lake/river water volumes [3]. Therefore, the absence of global large continental ice shields in both hemispheres during the mid-Cretaceous [2,3,55] is largely controlled by accelerated global warming greenhouse effect that resulted in: (1) melting of continental ice caps that was accompanied by the retreat of ice sheet on ice-shelves; and (2) seawater thermal expansion and increased ocean water temperature $[56,57]$. Thus, the long-term variation of sea level during the mid-Cretaceous greenhouse and hothouse climate is likely interrelated with eustatic sea level and related processes of ocean floor spreading and ocean crust production [1-3].

On a regional scale, throughout the tropics, where our study area was located at $\sim 8^{\circ} \mathrm{N}$ of the equator, a long-term transgression of the Tethys estimated between 100 and $150 \mathrm{~m}$ is seen through the whole study succession during the late Coniacian-earliest Campanian interrupted by minor short-term regression phases. The deposition of the transgressive hemipelagic carbonates of the Abu Roash A Member were interrupted by argillaceous limestone and minor calcareous shale streaks during minor short-term progradation of the sea level, which was characterized by a plethora of warming dinocyst-indicator groups and a negative $\delta^{18} \mathrm{O}$ trend until the mid-Santonian (Figure 7 , Supplementary Table S2). From the mid-Santonian onwards, a gradual cooling trend was observed that accelerated at the top part of the study succession [24,55]. In-parallel, a significantly rich palynomorphs, mainly warm-temperate dinocysts, at low-latitude, tropical North Atlantic interval from the Tarfaya Basin of Cenomanian-early Santonian age deposited during an inter-related warm greenhouse climate with high sea level and strong upwelling-system, was fully addressed by Prauss [58]. Therefore, the current study through the Cretaceous Abu Gharadig Basin includes significant variations of palynological records along with the isotopic and geochemical characterization that are in a good agreement with the counterpart time-wise study of Prauss [58]. This reveals a clear association between the regionally evidenced warm greenhouse of past-bottom and surface water temperatures at tropical low-latitude regions versus long-term transgression along with low-order sea-level fluctuations during the Coniacian-earliest Campanian. More high-resolution and independently constructed sea-level frameworks from other basins at tropical/subtropical areas, either within the Tethys or the Atlantic, are needed to further emphasize this issue.

\section{Conclusions}

Palynological composition from the southern Tethys Abu Gharadig Basin was dominated by a highly diverse assemblage of dinocysts, represented by two thirds of gonyaulacoids, which indicated a comparable pattern to the global sea level. The dinocyst content, along with MFTLs, FWA, sporomorphs, and PMI provided a reliable reconstruction of short-term sea level changes for the Upper Cretaceous hemipelagic sediments (Abu Roash A Member, $180 \mathrm{~m}$ ). The proposed aims of this study were achieved and resulted in defining a long-term transgression with minor short-term regressive phases in the sea 
level, which were further divided into four complete $3^{\text {rd }}$ order transgressive-regressive sequences and two incomplete ones. Considerable fluctuations were reported in elemental ratios of $\mathrm{Si} / \mathrm{Al}, \mathrm{Sr} / \mathrm{Ca}$, $\mathrm{Ti} / \mathrm{Al}$, and $\mathrm{Zr} / \mathrm{Al}$, whereby falling values matched well with regressive phases of sea level and rising values accompanied sea level transgressive phases. The relative increase of Mn content was associated with a sea-level rise compared to decreasing trends that accompany sea-level fall. In the Abu Roash A Member, the Mn profile showed a strong correlation with $\mathrm{Si}$ and $\mathrm{Al}$ at several intervals compared to a moderate correlation with $\mathrm{CaCO}_{3}$. This suggests that the $\mathrm{Mn}$ profile can be triggered by a terrestrial flux rather than by autochthonous marine generation.

Calibration of the $\delta^{13} \mathrm{C}_{\text {carb }}$ and $\delta^{18} \mathrm{O}_{\text {carb }}$ with palynomorphs composition, mainly gonyaulacoids and FWA-pteridophytic spores, was conducted on the hemipelagic carbonate Abu Roash A Member as an example from the southern Tethys. We revealed that positive $\delta^{13} C_{\text {carb }}$ trends can be consistent with enhanced gonyaulacoid dinocysts, indicating a rising sea level, whereas negative $\delta^{13} \mathrm{C}_{\text {carb }}$ trends were consistent with excess FWA-spores profiles, suggesting a falling sea level. The $\delta^{18} \mathrm{O}$ profile showed a reverse pattern to the gonyaulacoid dinocysts, whereby negative trends were consistent with high gonyaulacoid and low FWA-spores contents, reflecting a sea level transgressive phase. In contrast, positive $\delta^{18} \mathrm{O}$ trends were consistent with low gonyaulacoid content, indicating a sea level regressive phase. However, stable isotope profiles were not always consistent with palynological calibration, thus they can only be used as indicators of major changes in long-term sea level rather than short-term fluctuations. A climate-based relationship with sea level showed that the prevalence of warm-temperate dinocysts at the low-latitude Tethys and Atlantic, matched well with the high transgressive eustatic sea level during this time period.

Supplementary Materials: The following are available online at http://www.mdpi.com/2075-163X/10/12/1099/s1, Supplementary Table S1: Quantitative distribution of the palynomorphs categories from the studied succession in the BED 2-3 well, Supplementary Table S2: Carbon and oxygen isotope chemostratigraphy for the studied samples in the BED2-3 well, Supplementary Table S3: Quantitative vertical distribution of the most significant water column dinocysts. Dinocyst values shown as percentages. Chat = Chatangiella group, Isabel = Isabelidinium group, Trithy., Spinid = Trithyrodinium and Spinidinium group, Satyro., Alter = Satyrodinium and Alterbidinium group, Subtil $=$ Subtilisphaera group, Palaeoh $=$ Palaeohystrichophora group, $B$. spi. $=$ Bosedinia spinosa, B. alv = Bosedinia alveolata, B. laev $=$ Bosedinia laevigata, FWA $=$ Freshwater algae, MFTL $=$ Microforaminiferal test linings, $\mathrm{P} / \mathrm{G}=$ peridinioid/gonyaulacoid ratio., Supplementary Table S4: Illustrates correlation between various parameters of the current study samples.

Author Contributions: Conceptualization, A.M. and M.W.; Methodology and software, A.M.; validation, M.W., T.G., and S.T., formal analysis, M.W., investigation, A.M., and M.W.; resources and data curation, M.W., S.S.T. and A.M.T.E.; writing—original draft preparation, A.M., writing-review and editing, A.M., M.W., T.G., and A.M.T.E.; visualization, supervision, and project administration, M.W., T.G., S.S.T., and A.M.T.E. All authors have read and agreed to the published version of the manuscript.

Funding: This research received no external funding

Acknowledgments: The authors are grateful to the Egyptian General Petroleum Corporation for the permission of samples processing for the present study. Christoph Spötl (University of Innsbruck, Austria) is thanked for measuring bulk carbonate carbon and oxygen isotopes. Additionally, we thank three anonymous reviewers who suggested insightful and constructive comments that much enhanced this work. Finally, we would express our sincere gratitude to Aleksandra Milićev, Assistant Editor of Minerals, for handling the original and revised manuscripts of this paper. This work was carried out as part of the first author's Ph.D. project during a funded six-month study visit from the Egyptian Missions Sector, Ministry of Higher Education, Egypt, in co-operation with the University of Vienna, Austria.

Conflicts of Interest: The authors declare no conflict of interest.

\section{References}

1. Conrad, C.P. The solid Earth's influence on sea-level. Geol. Soc. Am. Bull. 2013, 125, 1027-1052. [CrossRef]

2. Haq, B.U. Cretaceous eustasy revisited. Glob. Planet. Chang. 2014, 113, 44-58. [CrossRef]

3. Sames, B.; Wagreich, M.; Wendler, J.E.; Haq, B.U.; Conrad, C.P.; Melinte-Dobrinescu, M.C.; Hu, X.; Wendler, I.; Wolfgring, E.; Yilmaz, I.Ö.; et al. Review: Short-term sea-level changes in a greenhouse world-A view from the Cretaceous. Palaeogeogr. Palaeoclimatol. Palaeoecol. 2016, 441, 393-411. [CrossRef] 
4. An, K.; Chen, H.; Lin, X.; Wang, F.; Yang, S.; Wen, Z.; Wang, Z.; Zhang, G.; Tong, X. Major transgression during Late Cretaceous constrained by basin sediments in northern Africa: Implication for global rise in sea level. Front. Earth Sci. 2017. [CrossRef]

5. Bujak, J.P.; Williams, G.L. Dinoflagellate diversity through time. Mar. Micropaleontol. 1979, 4, 1-12. [CrossRef]

6. MacRae, R.A.; Fensome, R.A.; Williams, G.L. Fossil dinoflagellate diversity, originations, and extinctions and their significance. Can. J. Bot. 1996, 74, 1687-1694. [CrossRef]

7. Gradstein, F.M.; Ogg, J.G.; Schmitz, M.D.; Ogg, G.M. The Geologic Time Scale, 1st ed.; Elsevier: Amsterdam, The Netherlands, 2012; 1144p.

8. Prauss, M.L. The Cenomanian/Turonian Boundary Event (CTBE) at Wunstorf, north-west Germany, as reflected by marine palynology. Cretac. Res. 2006, 27, 872-886. [CrossRef]

9. Tyson, R.V. Sedimentary Organic Matter-organic Facies and Palynofacies; Chapman and Hall: London, UK, 1995; p. 615.

10. Skupien, P. Upper Cretaceous dinoflagellates and palaeonvironmental change of the Silesian basin (Outer Western Carpathians). Geophys. Res. Abstr. 2007, 9, 02355.

11. Pearce, M.A.; Jarvis, I.; Tocher, B.A. The Cenomanian-Turonian boundary event, OAE2 and palaeoenvironmental change in epicontinental seas: New insights from dinocyst and geochemical records. Palaeogeogr. Palaeoclimatol. Palaeoecol. 2009, 280, 207-234. [CrossRef]

12. Olde, K.; Jarvis, I.; Uličný, D.; Pearce, M.A.; Trabucho-Alexandre, J.; Čech, S.; Gröcke, D.R.; Laurin, J.; Švábenická, L.; Tocher, B.A. Geochemical and palynological sea-level proxies in hemipelagic sediments: A critical assessment from the Upper Cretaceous of the Czech Republic. Palaeogeogr. Palaeoclimatol. Palaeoecol. 2015, 435, 222-243. [CrossRef]

13. Tahoun, S.S.; Deaf, A.S.; Mansour, A. Palynological, paleoenvironmental and sequence stratigraphical analyses of a Turonian-Coniacian sequence, Beni Suef Basin, Eastern Desert, Egypt: Implication of Pediastrum rhythmic signature. Mar. Pet. Geol. 2017, 88, 871-887. [CrossRef]

14. Mansour, A.; Tahoun, S.S.; Gentzis, T.; Elewa, A.M.T. The marine palynology of the Upper Cretaceous Abu Roash 'A' Member in the BED 2-3 borehole, Abu Gharadig Basin, Egypt. Palynology 2020, 44, 167-186. [CrossRef]

15. van Wagoner, J.C.; Posamentier, H.W.; Mitchum, R.M.; Vail, P.R.; Sarg, J.F.; Loutit, T.S.; Hdenbol, J. An overview of the fundamentals of sequence stratigraphy and key definitions. In Sea-Level Changes: An Integrated Approach; Special Publication; Society of Economic and Paleontologists and Mineralogists: Tulsa, OK, USA, 1988; Volume 42, pp. 39-45.

16. Catuneanu, O.; Galloway, W.E.; Kendall, C.G.S.C.; Miall, A.D.; Posamentier, H.W.; Strasser, A.; Tucker, M.E. Sequence Stratigraphy: Methodology and Nomenclature. Newsl. Stratigr. 2011, 44, 173-245. [CrossRef]

17. Emery, D. Chapter Ten: Carbonate Systems. In Sequence Stratigraphy; Emery, D., Myers, K., Eds.; Blackwell Science: Hoboken, NJ, USA, 1996; pp. 211-237.

18. Jarvis, I.; Murphy, A.M.; Gale, A.S. Geochemistry of pelagic and hemipelagic carbonates: Criteria for identifying systems tracts and sea-level change. J. Geol. Soc. Lond. 2001, 158, 685-696. [CrossRef]

19. Jarvis, I.; Mabrouk, A.; Moody, R.T.J.; Murphy, A.M.; Sandman, R.I. Applications of carbon isotope and elemental ( $\mathrm{Sr} / \mathrm{Ca}, \mathrm{Mn}$ ) chemostratigraphy to sequence analysis: Sea-level change and the global correlation of pelagic carbonates. In Geology of East Libya; Salem, M.J., El-Hawat, A.S., Eds.; Earth Science Society of Libya: Tripoli, Libya, 2008; pp. 369-396.

20. Jarvis, I.; Trabucho-Alexandre, J.; Gröcke, D.R.; Uličný, D.; Laurin, J. Stable isotope chemostratigraphy: Intercontinental correlation of organic carbon and carbonate records, and evidence of climate and sea-level change during the Turonian (Cretaceous). Depos. Rec. 2015, 1, 53-90. [CrossRef]

21. Le Callonnec, L.; Renard, M.; De Rafélis, M.; Minoletti, F.; Beltran, C.; Du Chene, R.J. Evolution of the trace element contents ( $\mathrm{Sr}$ and $\mathrm{Mn}$ ) of hemipelagic carbonates from the Zumaia Paleocene section (Gipuzkoa, Spain): Implications for the knowledge of seawater chemistry during the Selandian. Bull. Société Géologique Fr. 2014, 185, 413-435. [CrossRef]

22. Wagreich, M.; Koukal, V. The pelagic archive of short-term sea-level change in the Cretaceous: A review of proxies linked to orbital forcing. Geol. Soc. Lond. Spec. Publ. 2019, 498, 39-56. [CrossRef]

23. Mansour, A.; Wagreich, M.; Gentzis, T.; Ocubalidet, S.; Tahoun, S.S.; Elewa, A.M.T. Depositional and organic carbon-controlled regimes during the Coniacian-Santonian event: First results from the southern Tethys (Egypt). Mar. Pet. Geol. 2020, 115, 104285. [CrossRef] 
24. Stoll, H.M.; Schrag, D.P. High-resolution stable isotope records from the Upper Cretaceous rocks of Italy and Spain: Glacial episodes in a greenhouse planet? Geol. Soc. Am. Bull. 2000, 112, 308-319. [CrossRef]

25. Wendler, I. A critical evaluation of carbon isotope stratigraphy and biostratigraphic implications for Late Cretaceous global correlation. Earth-Sci. Rev. 2013, 126, 116-146. [CrossRef]

26. Sabatino, N.; Meyers, S.R.; Voigt, S.; Coccioni, R.; Sprovieri, M.; Coccioni, R.; Sprovieri, M. A new high-resolution carbon-isotope stratigraphy for the Campanian (Bottaccione section): Its implications for global correlation, ocean circulation, and astrochronology. Palaeogeogr. Palaeoclimatol. Palaeoecol. 2018, 489, 29-39. [CrossRef]

27. Guiraud, R.; Bellion, Y. Late Carboniferous to Recent geodynamic evolution of the west Gondwanian cratonic Tethyan margins. In The Ocean Basins and Margins; Narin, A.E.M., Stehli, F.G., Eds.; The Tethys Ocean, Plenum: New York, NY, USA, 1995; Volume 8, pp. 101-124.

28. El Gazzar, A.M.; Moustafa, A.R.; Bentham, P. Structural evolution of the Abu Gharadig field area, northern Western Desert, Egypt. J. Afr. Earth Sci. 2016, 124, 340-354. [CrossRef]

29. Hendy, H.; Gouda, S.; Ghanem, L. Structural styles revealed by 3D seismic data in Badr El Din and Sitra Lease areas, Western Desert, Egypt. In Proceedings of the EGPC 11th Petroleum Exploration and Production Conference, Cairo, Egypt, 7-10 November 1992; pp. 20-38.

30. Guiraud, R.; Bosworth, W. Senonian basin inversion and rejuvenation of rifting in Africa and Arabia: Synthesis and implications to plate-scale tectonics. Tectonophysics 1997, 282, 39-82. [CrossRef]

31. Scotese, C.R. Modern Plate Tectonic Globe; (Modern_Ptect_766.kmz, Google Earth format); PALEOMAP Project: Evanston, IL, USA, 2014. Available online: www.globalgeology.com (accessed on 1 June 2014).

32. Hantar, G. North Western Desert. In The Gelogy of Egypt; Said, R., Ed.; Balkema: Rotterdam, The Netherlands, 1990; Chapter 15; pp. 293-319.

33. Abdel-Kireem, M.R.; Schrank, E.; Samir, A.M.; Ibrahimi, M.I.A. Cretaceous palaeoecology, palaeogeography. and palaeoclimatology of the northern Western Desert, Egypt. J. Afr. Earth Sci. 1996, 22, 93-112. [CrossRef]

34. Wood, G.D.; Gabriel, A.M.; Lawson, J.C. Palynological techniques_Processing and microscopy. In Palynology: Principles and Applications; Jansonius, J., McGregor, D.C., Eds.; American Association of Stratigraphic Palynologist Foundation: Dallas, TX, USA, 1996; Volume 1, pp. 29-50.

35. Müller, G.; Gastner, M. The "Karbonat-Bombe", a simple device for the determination of the carbonate content in sediments, soils, and other materials. Neues Jahrb. Mineral. Mon. 1971, 10, 466-469.

36. Spötl, C.; Vennemann, T. Continuous-flow isotope ratio mass spectrometric analysis of carbonate minerals. Rapid Commun. Mass Spectrom. 2003, 17, 1004-1006. [CrossRef]

37. Spellerberg, I.F.; Fedor, P.J. A tribute to Claude Shannon (1916-2001) and a plea for more rigorous use of species richness, species diversity and the 'Shannon-Wiener' Index. Glob. Ecol. Biogeogr. 2003, 12, 177-179. [CrossRef]

38. Jacobsen, S.B.; Kaufman, A.J. The Sr, C and O isotopic evolution of Neoproterozoic seawater. Chem. Geol. 1999, 161, 37-57. [CrossRef]

39. Bradford, M.R.; Wall, D.A. The distribution of recent organic walled dinoflagellate cysts in the Persian Gulf of Oman and northwestern Arabian Sea. Palaeonto. Abteilung B-Palaophytol. 1984, 192, 16-84.

40. Brinkhuis, H. Late Eocene to early Oligocene dinoflagellate cysts from the Priabonian type-area (Northeast Italy): Biostratigraphy and paleoenvironmental interpretation. Palaeogeogr. Palaeoclimatol. Palaeoecol. 1994, 107, 121-163. [CrossRef]

41. Götz, A.E.; Feist-Burkhardt, S.; Ruckwied, K. Palynofacies and sea-level changes in the upper Cretaceous of the Vocontian Basin, Southeast France. Cretac. Res. 2008, 29, 1047-1057. [CrossRef]

42. Helenes, J.; De-Guerra, C.; Vásquez, J. Palynology and chronostratigraphy of the upper Cretaceous in the subsurface of the Barinas area, western Venezuela. Am. Assoc. Pet. Geol. Bull. 1998, 82, 1308-1328.

43. Deaf, A.S.; Tahoun, S.S. Integrated palynological, organic geochemical, and sequence stratigraphic analyses of the middle to upper Cenomanian hydrocarbon reservoir/source Abu Roash "G" Member: A depositional model in northwestern Egypt. Mar. Pet. Geol. 2018, 92, 372-402. [CrossRef]

44. Zippi, P.A. Freshwater algae from the Mattagami Formation (Albian), Ontario: Paleoecology, botanical affinities, and systematic taxonomy. Micropaleontology 1998, 44, 1-78. [CrossRef]

45. Brenac, P.; Richards, K. Pediastrum as a guide fossil in sequence stratigraphy. In Proceedings of the IX International Palynological Congress, Houston, TX, USA, 23-28 June 1996; Goodman, D.K., Clarke, R.T., Eds.; American Association of Stratigraphic Palynologists Foundation: Houston, TX, USA, 2001; pp. $239-241$. 
46. Schlanger, S.O. Strontium storage and release during deposition and diagenesis of marine carbonates release to sea-level variations. In Physical and Chemical Weathering in Geochemical Cycles; Lerman, A., Meybeck, M., Eds.; Kluwer Academic: Dordrecht, The Netherlands, 1988; pp. 323-339.

47. Li, L.; Keller, G.; Adatte, T.; Stinnesbeck, W. Late Cretaceous sea level changes in Tunisia: A multidisciplinary approach. J. Geol. Soc. Lond. 2000, 157, 447-458. [CrossRef]

48. Ruf, M.; Link, E.; Prossb, J.; Aigner, T. Integrated sequence stratigraphy: Facies, stable isotope and palynofacies analysis in a deeper epicontinental carbonate ramp (Late Jurassic, SW Germany). Sediment. Geol. 2005, 175, 391-414. [CrossRef]

49. Marshall, J.D. Climatic and oceanographic isotope signals from the carbonate rock record and their preservation. Geol. Mag. 1992, 129, 143-160. [CrossRef]

50. Jenkyns, H.C.; Gale, A.S.; Corfield, R.M. Carbon and oxygen-isotope stratigraphy of the English Chalk and Italian Scaglia and its palaeoclimatic significance. Geol. Mag. 1994, 131, 1-34. [CrossRef]

51. Jarvis, I.; Gale, A.S.; Jenkyns, H.C.; Pearce, M.A. Secular variation in Late Cretaceous carbon isotopes: A new $\delta^{13} \mathrm{C}$ carbonate reference curve for the Cenomanian-Campanian (99.6-70.6 Ma). Geol. Mag. 2006, 143, 561-608. [CrossRef]

52. Arthur, M.A.; Anderson, T.F.; Kaplan, I.R.; Veizer, J.; Land, L.S. Stable Isotopes in Sedimentary Geology; Society of Economic and Paleontologists and Mineralogists: Tulsa, OK, USA, 1983.

53. Shackleton, N.J. Oxygen isotopes, ice volume and sea level. Quat. Sci. Rev. 1987, 6, 183-190. [CrossRef]

54. Föllmi, K. Early Cretaceous life, climate and anoxia. Cretac. Res. 2012, 35, 230-257. [CrossRef]

55. Linnert, C.; Robinson, S.A.; Lees, J.A.; Bown, P.A.; Pérez-Rodriguez, I.; Petrizzo, M.R.; Falzoni, F.; Littler, K.; Arz, J.A.; Russell, E.E. Evidence for global cooling in the Late Cretaceous. Nat. Commun. 2014, 5, 4194. [CrossRef]

56. Church, J.A.; Roemmich, D.; Domingues, C.M.; Willis, J.K.; White, N.J.; Gilson, J.E.; Stammer, D.; Köhl, A.; Chambers, D.P.; Landerer, F.W.; et al. Ocean temperature and salinity contributions to global and regional sea-level change. In Understanding Sea-Level Rise and Variability, 1st ed.; Church, J.A., Woodworth, P.L., Aarup, T., Wilson, W.S., Eds.; Wiley-Blackwell: Chichester, UK, 2010; pp. 143-176.

57. Alley, R.B.; Anandakrishnan, S.; Christianson, K.; Horgan, H.J.; Muto, A.; Parizek, B.R.; Pollard, D.; Walker, R.T. Oceanic forcing of ice sheet retreat: West Antarctica. Annu. Rev. Earth Planet. Sci. 2015, 43, 207-231. [CrossRef]

58. Prauss, M.L. Marine palynology of the Oceanic Anoxic Event 3 (OAE3, Coniacian-Santonian) at Tarfaya, Morocco, NW Africa-Transition from preservation to production-controlled accumulation of marine organic carbon. Cretac. Res. 2015, 53, 19-37. [CrossRef]

Publisher's Note: MDPI stays neutral with regard to jurisdictional claims in published maps and institutional affiliations.

(C) 2020 by the authors. Licensee MDPI, Basel, Switzerland. This article is an open access article distributed under the terms and conditions of the Creative Commons Attribution (CC BY) license (http://creativecommons.org/licenses/by/4.0/). 